University of Tennessee Health Science Center UTHSC Digital Commons

\title{
Antimicrobial Activity of Human Leukocyte Defensin HNP-4 Against Gram-negative Bacteria
}

\author{
George Hilal \\ University of Tennessee Health Science Center
}

Follow this and additional works at: https://dc.uthsc.edu/dissertations

\section{Recommended Citation}

Hilal, George , "Antimicrobial Activity of Human Leukocyte Defensin HNP-4 Against Gram-negative Bacteria" (2008). Theses and Dissertations (ETD). Paper 125. http://dx.doi.org/10.21007/ etd.cghs.2008.0137.

This Thesis is brought to you for free and open access by the College of Graduate Health Sciences at UTHSC Digital Commons. It has been accepted for inclusion in Theses and Dissertations (ETD) by an authorized administrator of UTHSC Digital Commons. For more information, please contact jwelch30@uthsc.edu. 


\title{
Antimicrobial Activity of Human Leukocyte Defensin HNP-4 Against Gram- negative Bacteria
}

\author{
Abstract \\ Human neutrophils (PMN cells) contain four peptides known as alpha ( $\alpha$ )-defensins or HNP 1-4. The \\ peptides have broad-spectrum antibiotic activity. HNP 1-3 are major neutrophil components. They differ \\ by only one amino acid residue. HNP-4 is found in small amounts, and has a different sequence. HNP-4 \\ purified from neutrophils was reported to be 100-times more active than HNP-1 against Escherichia coli, \\ suggesting that HNP-4 plays a special role in helping neutrophils kill gram-negative bacteria. \\ Activity of HNP-4 against gram-negative bacteria is of special interest because Aggregatibacter \\ (Actinobacillus) actinomycetemcomitans (A.a.) and other periodontal pathogens are gram-negative. \\ These bacteria are resistant to HNP 1-3. Defensin-resistance may contribute to the ability of these \\ bacteria to cause disease. There have been no studies of HNP-4 activity against oral bacteria, because \\ HNP-4 is found in small amounts and is difficult to purify. Recently, HNP-4 was chemically synthesized, \\ making it possible to study its antibacterial activity. However, synthetic HNP-4 was reported to be no \\ more active than HNP-1 against E. coli.
}

Lipopolysaccharide (LPS) covers the surface of gram-negative bacteria. Each LPS molecule has three parts: a long carbohydrate chain (oligosaccharide) that is exposed on the cell surface, a short carbohydrate core, and lipid A that anchors LPS in the outer membrane. LPS on the bacterial cell surface may be the receptor for HNP-4 and other peptides that kill gram-negative bacteria.

Our aims were to: (1) Compare the purity and physical properties of purified and synthetic HNP-4. (2) Compare activity of synthetic and purified HNP-4 against E. coli. (3) Determine whether synthetic HNP-4 binds to purified E. coli LPS. (4) Locate the HNP-4 binding site for synthetic HNP-4 on E. coli LPS molecules. (5) Measure activity of synthetic HNP-4 against A.a. (6) Compare binding of synthetic HNP-4 to LPS purified from E. coli and A.a.

Results: (1) Purified and synthetic HNP-4 were of high purity. They had the same molecular mass, which was equal to the mass calculated from the amino acid sequence. (2) Activity of purified and synthetic HNP-4 against E. coli was the same, and similar to the activity of HNP-1. (3) LPS purified from E. coli absorbed synthetic HNP-4. (4) Experiments with LPS fragments showed that synthetic HNP-4 was absorbed to the LPS inner core. (5) Synthetic HNP-4 partially inhibited growth of A.a. but did not kill these bacteria. (6) There was no difference in the ability of E. coli or A.a. LPS to absorb synthetic HNP-4.

The results suggest that HNP- 4 is not more active than other neutrophil $\alpha$-defensins against gramnegative bacteria. The results also indicate that LPS on the surface of gram-negative bacteria could be the receptor for HNP-4. Because HNP-4 binds to the LPS inner core, HNP-4 may help neutrophils kill gramnegative bacteria that lack oligosaccharide and the LPS outer core.

The periodontal pathogen A.a. is resistant to all of the human leukocyte $\alpha$-defensins including HNP-4. Therefore, synthetic HNP-4 is not likely to be used in dental practice to prevent or treat oral disease. Resistance of A.a. to HNP-4 is not the result of a difference in LPS structure that interferes with HNP-4 binding. Further studies are needed to determine the mechanism of defensin resistance.

\section{Document Type}

Thesis 


\section{Degree Name}

Master of Dental Science (MDS)

\section{Program}

Periodontology

\section{Research Advisor}

Edwin L. Thomas, Ph.D.

\section{Keywords}

Defensin, Cationic Antimicrobial Peptides, Periodontal Pathogens, Lipopolysaccharide 


\title{
ANTIMICROBIAL ACTIVITY \\ OF HUMAN LEUKOCYTE DEFENSIN HNP-4 \\ AGAINST GRAM-NEGATIVE BACTERIA
}

\author{
A Thesis \\ Presented for \\ The Graduate Studies Council \\ The University of Tennessee \\ Health Science Center
}

\author{
In Partial Fulfillment \\ Of the Requirements for the Degree \\ Master of Dental Science \\ From The University of Tennessee
}

By

George E. Hilal, D.M.D.

May 2008 
Copyright (C) 2008 by George E. Hilal All rights reserved 


\section{DEDICATION}

I dedicate this thesis to my wife, Kimberly Hilal, and my family for their continuous love and support. 


\section{ACKNOWLEDGMENTS}

I would like to thank Dr. Edwin L. Thomas for being a great mentor throughout this master's thesis project and for allowing me to be part of his ongoing studies. I can't thank him enough for the time and effort spent with me in order to make this project possible.

I would like to thank my Committee members Drs. Jegdish P. Babu, David A. Tipton, and Paul S. Bland for their valuable support and suggestions.

I would like to express my sincere appreciation to Mary Margaret Jefferson for her tremendous help with lab work, literature, and purifying the HNP-4. I am very grateful for the hours spent to make this thesis possible.

I would like to thank Dr. Jegdish P. Babu for providing A.a. LPS and Dr. Wuyuan $\mathrm{Lu}$ at the University of Maryland Biotechnology Institute for providing synthetic HNP-4. Without their help this project would have been impossible to achieve.

I am also thankful to the University of Tennessee College of Dentistry Alumni Endowment Fund for its financial support of this project. 


\begin{abstract}
Human neutrophils (PMN cells) contain four peptides known as alpha $(\alpha)$ defensins or HNP 1-4. The peptides have broad-spectrum antibiotic activity. HNP 1-3 are major neutrophil components. They differ by only one amino acid residue. HNP-4 is found in small amounts, and has a different sequence. HNP-4 purified from neutrophils was reported to be 100-times more active than HNP-1 against Escherichia coli, suggesting that HNP-4 plays a special role in helping neutrophils kill gram-negative bacteria.
\end{abstract}

Activity of HNP-4 against gram-negative bacteria is of special interest because Aggregatibacter (Actinobacillus) actinomycetemcomitans (A.a.) and other periodontal pathogens are gram-negative. These bacteria are resistant to HNP 1-3. Defensin-resistance may contribute to the ability of these bacteria to cause disease. There have been no studies of HNP-4 activity against oral bacteria, because HNP-4 is found in small amounts and is difficult to purify. Recently, HNP-4 was chemically synthesized, making it possible to study its antibacterial activity. However, synthetic HNP-4 was reported to be no more active than HNP-1 against E. coli.

Lipopolysaccharide (LPS) covers the surface of gram-negative bacteria. Each LPS molecule has three parts: a long carbohydrate chain (oligosaccharide) that is exposed on the cell surface, a short carbohydrate core, and lipid A that anchors LPS in the outer membrane. LPS on the bacterial cell surface may be the receptor for HNP-4 and other peptides that kill gram-negative bacteria.

Our aims were to: (1) Compare the purity and physical properties of purified and synthetic HNP-4. (2) Compare activity of synthetic and purified HNP-4 against E. coli. (3) Determine whether synthetic HNP-4 binds to purified E. coli LPS. (4) Locate the HNP-4 binding site for synthetic HNP-4 on E. coli LPS molecules. (5) Measure activity of synthetic HNP-4 against A.a. (6) Compare binding of synthetic HNP-4 to LPS purified from E. coli and A.a.

Results: (1) Purified and synthetic HNP-4 were of high purity. They had the same molecular mass, which was equal to the mass calculated from the amino acid sequence. (2) Activity of purified and synthetic HNP-4 against E. coli was the same, and similar to the activity of HNP-1. (3) LPS purified from E. coli absorbed synthetic HNP-4. (4) Experiments with LPS fragments showed that synthetic HNP-4 was absorbed to the LPS inner core. (5) Synthetic HNP-4 partially inhibited growth of A.a. but did not kill these bacteria. (6) There was no difference in the ability of E. coli or A.a. LPS to absorb synthetic HNP-4.

The results suggest that HNP-4 is not more active than other neutrophil alphadefensins against gram-negative bacteria. The results also indicate that LPS on the surface of gram-negative bacteria could be the receptor for HNP-4. Because HNP-4 
binds to the LPS inner core, HNP-4 may help neutrophils kill gram-negative bacteria that lack oligosaccharide and the LPS outer core.

The periodontal pathogen A.a. is resistant to all of the human leukocyte alphadefensins including HNP-4. Therefore, synthetic HNP-4 is not likely to be used in dental practice to prevent or treat oral disease. Resistance of A.a. to HNP-4 is not the result of a difference in LPS structure that interferes with HNP-4 binding. Further studies are needed to determine the mechanism of defensin resistance. 


\section{TABLE OF CONTENTS}

CHAPTER 1: INTRODUCTION AND LITERATURE REVIEW ............ 1

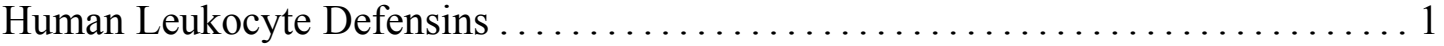

Periodontal Pathogens and Defensins . . . . . . . . . . . . . . . 3

Lipopolysaccharide and Gram-negative Bacteria $\ldots \ldots \ldots \ldots \ldots \ldots \ldots$

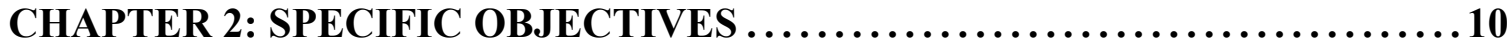

CHAPTER 3: MATERIALS AND METHODS $\ldots \ldots \ldots \ldots \ldots \ldots \ldots \ldots \ldots \ldots \ldots$

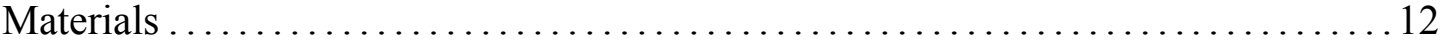

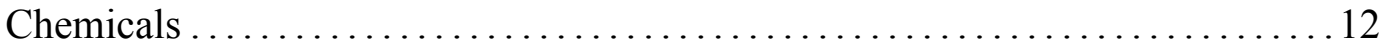

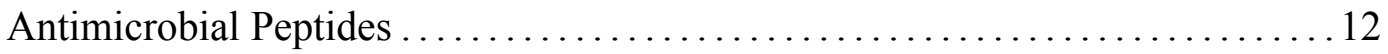

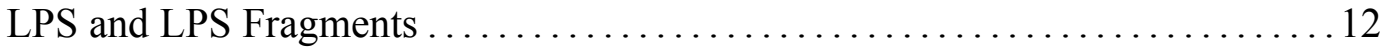

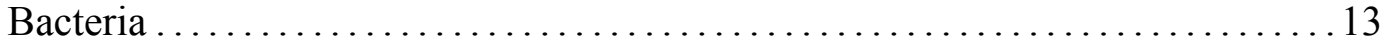

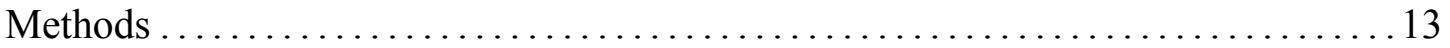

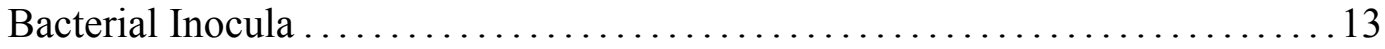

Bacterial Cultures .......................................... 13

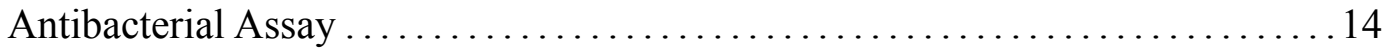

MALDI-TOF Mass Spectrometry ...................................... 14

Estimated Molecular Weights of LPS and Fragments .................. 15

Data Analysis . . . . . . . . . . . . . . . . . . . . . . . . . . . . 15

CHAPTER 4: RESULTS $\ldots \ldots \ldots \ldots \ldots \ldots \ldots \ldots \ldots \ldots \ldots \ldots \ldots \ldots \ldots \ldots \ldots \ldots \ldots \ldots$

Physical Properties of Synthetic and Purified HNP-4 ................... 17

MALDI-TOF Mass Spectrometry . . . . . . . . . . . . . . . . . . . . 17

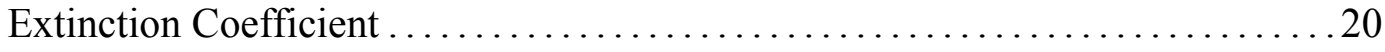

Activity of Synthetic and Purified HNP-4 against E. coli .................. 20

Killing of $E$. coli ML-35 by Synthetic HNP-4 ..................... 20

Killing of $E$. coli ML-35 by Purified HNP-4 ..................... 21

Killing of E. coli Serotype O111:B4 by Synthetic HNP-4 .................21

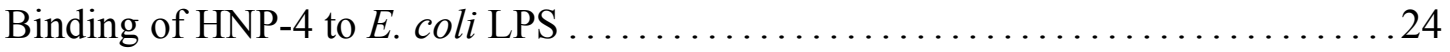

Blocking of HNP-4 Activity by LPS Fragments ...................... 24

Role of the Lipid A Part of LPS in HNP-4 Binding ..................... 24

Effect of Deacylated LPS on Killing by HNP-4 ..................24

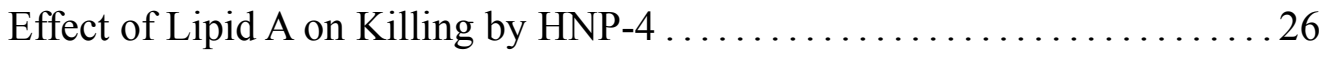

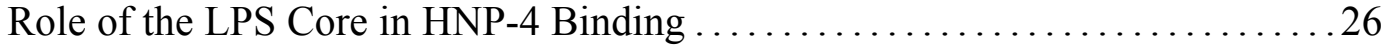

Effect of Kdo2-lipid A on Killing by HNP-4 ..................... 30

Effects of Re, Rc, and Ra LPS on Killing by HNP-4 ............... 30

Killing of $E$. coli J5 by HNP-4 ................................ 35

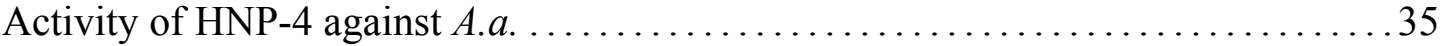

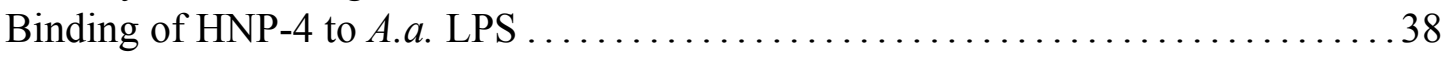




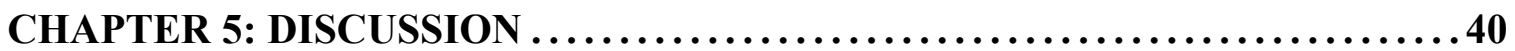

Physical Properties of Synthetic and Purified HNP-4 .................. 40

Activity of Synthetic and Purified HNP-4 against the Standard Test Organism .40

Binding of HNP-4 to E. coli LPS ................................ 40

LPS as the Receptor for HNP-4 ..............................41

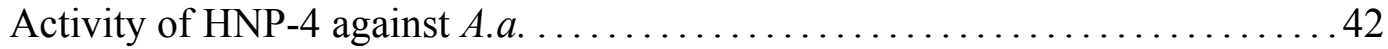

Binding of HNP-4 to A.a. LPS ............................... 43

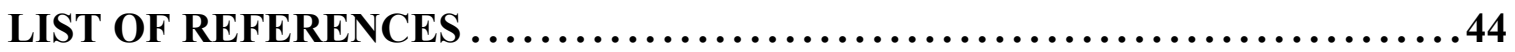

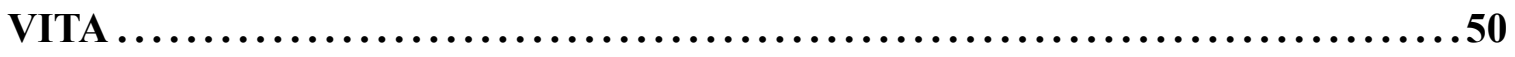




\section{LIST OF TABLES}

Table 3.1. Average molecular weights of LPS preparations $\ldots \ldots \ldots \ldots \ldots \ldots \ldots$

Table 5.1. Concentrations of LPS and LPS fragments that block $10 \mu \mathrm{M} \mathrm{HNP}-4$. . 42 


\section{LIST OF FIGURES}

Figure 1.1. Amino acid sequences of human leukocyte alpha-defensins ......2

Figure 1.2. Cut-away diagram of a gram-negative bacterium $\ldots \ldots \ldots \ldots \ldots$

Figure 1.3. Diagram of a section of the gram-negative cell envelope $\ldots \ldots \ldots \ldots 6$

Figure 1.4. Structures of LPS and the deacyl-LPS and lipid A fragments ...... 7

Figure 1.5. Structures of $E$. coli LPS and LPS from rough $(\mathrm{R})$ mutants .......9

Figure 4.1. Purity of the HNP-4 preparations $\ldots \ldots \ldots \ldots \ldots \ldots \ldots \ldots \ldots \ldots \ldots$

Figure 4.2. Molecular mass of purified and synthetic HNP-4 ............. 19

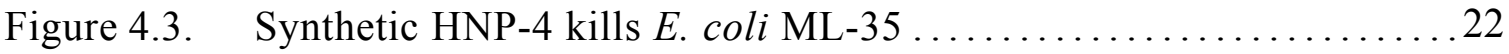

Figure 4.4. Synthetic HNP-4 kills E. coli of serotype O111:B4 ............23

Figure 4.5. E. coli LPS blocks HNP-4 killing of E. coli ML-35 .............25

Figure 4.6. Deacyl-LPS blocks HNP-4 killing of E. coli ML-35 ............27

Figure 4.7. Lipid A does not block HNP-4 killing of E. coli ML-35 ..........28

Figure 4.8. Structures of Kdon-lipid A and LPS from rough mutants . . . . . .. 29

Figure 4.9. Kdon-lipid A blocks HNP-4 killing of E. coli ML-35 ............ 31

Figure 4.10. Rough (Re) LPS blocks HNP-4 killing of E. coli ML-35 ..........32

Figure 4.11. Rough (Rc) LPS blocks HNP-4 killing of E. coli ML-35 . . . . . . 33

Figure 4.12. Rough (Ra) LPS blocks HNP-4 killing of E. coli ML-35 . . . . . . 34

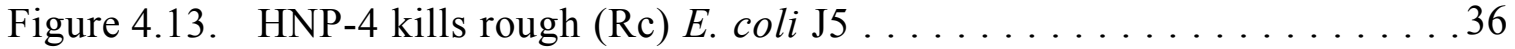

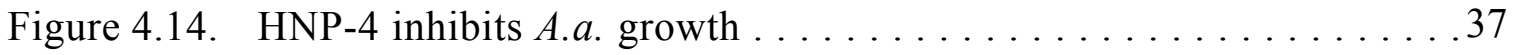

Figure 4.15. A.a. LPS blocks HNP-4 killing of E. coli ML-35 . . . . . . . . . . 39 


\section{LIST OF ABBREVIATIONS}

A.a. Aggregatibacter (Actinobacillus) actinomycetemcomitans

ATCC American Type Culture Collection

CAP Cationic Antimicrobial Peptide

CFU Colony Forming Units

Deacyl-LPS Deacylated-Lipopolysaccharide

E. coli Escherichia coli

F.n. Fusobacterium nucleatum

HNP Human Neutrophil Peptide

Kdo 3-Deoxy-D-manno-octulosonic Acid

Kdo2-lipid A Di[3-deoxy-D-manno-octulosonyl]-lipid A

LPS Lipopolysaccharide

MALDI-TOF Matrix-Assisted Laser Desorption and Ionization-Time Of Flight

PBS Phosphate Buffered Saline

P. g. Porphyromonas gingivalis

P. $i . \quad$ Prevotella intermedia

PMN Polymorphonuclear

TFA Trifluoroacetic Acid

TSB Trypticase Soy Broth 


\section{CHAPTER 1. INTRODUCTION AND LITERATURE REVIEW}

\section{Human Leukocyte Defensins}

Neutrophils (PMN leukocytes) are the first line of defense against infection. Neutrophils are the most abundant leukocytes in blood and make up about $50 \%$ of circulating leukocytes. Neutrophils are the first cells to respond to infection. They leave the bloodstream and migrate through the blood vessel walls and into the tissues in response to chemical signals released at sites of infection and inflammation. Numbers of neutrophils are high in oral tissues. They migrate into the oral tissues and are shed into the oral cavity at the gingival crevices $(1,2)$. The number of neutrophils in oral tissues increases greatly in patients with gingivitis and periodontitis (3).

Neutrophils are phagocytic cells. In the process of phagocytosis, neutrophils ingest micro-organisms and kill them in cell compartments called phagosomes. Neutrophils have two general mechanisms for killing micro-organisms (4). In oxidative killing, neutrophils produce superoxide anions and other oxidizing agents that kill micro-organisms by oxidizing essential cellular components. Neutrophils also contain high levels of antimicrobial enzymes such as lysozyme and other peptides and proteins with antimicrobial activity. These antimicrobial agents kill micro-organisms by non-oxidative mechanisms, such as by making microbial cell membranes leaky.

One class of non-oxidative antimicrobial agents found in neutrophils is a family of peptides known as alpha $(\alpha)$-defensins (5-7). These peptides have broad-spectrum antibiotic activity. They are able to kill fungi and gram-negative and gram-positive bacteria. Alpha-defensins are major neutrophil components, making up 5 to $7 \%$ of the total amount of protein in the cell (8).

Alpha-defensins are stored in secretory granules in the cytoplasm. They are released from the granules into phagosomes after the neutrophils phagocytize microorganisms. Alpha-defensins are also released from neutrophils into the environment outside the neutrophil when the cells are stimulated or during cell lysis. Alphadefensins have been detected in gingival crevicular fluid (9-10).

Human leukocyte alpha-defensins are examples of cationic antimicrobial peptides (CAPs), which are widely distributed in nature (11-13). Defensins are members of the family of cysteine-rich CAPs, which are found not only in vertebrates but in plants and insects (14-16). Alpha-defensins have a unique structure that differs from other defensins, and are found only in primates, rodents, and rabbits (7).

Three alpha-defensin peptides were isolated from human neutrophils (17) and named HNP (Human Neutrophil Peptide) 1-3 (Figure 1.1). The peptides are 


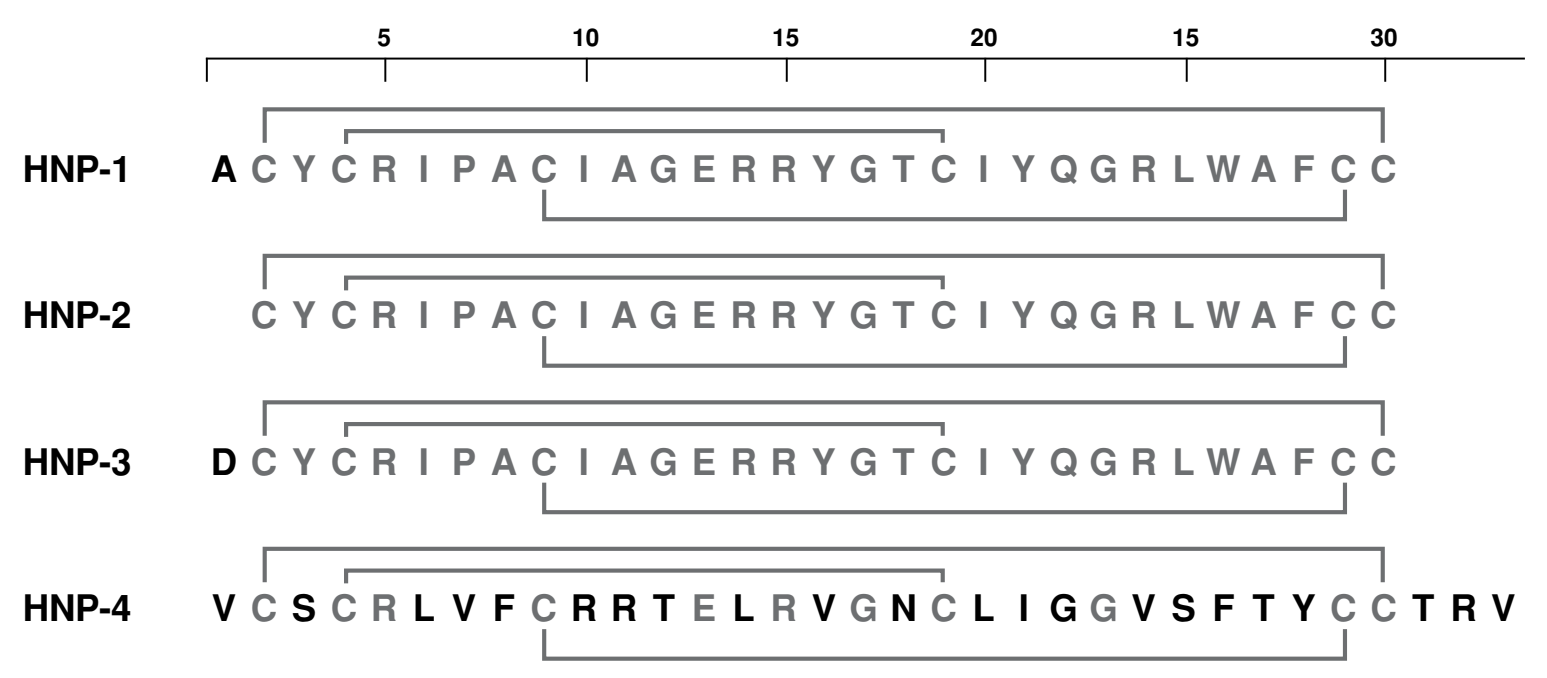

Figure 1.1. Amino acid sequences of human leukocyte alpha-defensins.

Amino acid residues that differ between the 4 peptides are shown in black. Residues that are the same are shown in gray.

arginine (R)-rich, which gives them a net positive (cationic) charge. They have 6 cysteine (C) residues (numbered 1-6 from the N-terminus), which form 3 intramolecular disulfide bonds. The disulfide bonds are from cysteine residues 1 to 6,2 to 4 , and 3 to 5. This arrangement of disulfide bonds is the unique structural feature of alpha-defensins (18).

HNP 1-3 have 30, 29, and 30 amino acid residues and molecular weights of 3442 , 3371 , and 3486 , respectively. The three peptides differ by only one amino acid residue at the N-terminus. At neutral $\mathrm{pH}$, the three peptides have a net positive charge of +3 . Most studies on human alpha-defensins have used HNP-1 or a mixture of HNP 1-3.

Later, a fourth human leukocyte alpha-defensin was discovered in human neutrophils (19) and was named HNP-4. Neutrophils have small amounts of HNP-4, only about $1 \%$ the amount of HNP 1-3. Figure 1.1 shows that the structure of HNP-4 is different from the structures of HNP 1-3. HNP-4 is arginine-rich, has 6 cysteine residues in the same positions as in HNP 1-3, and has 3 disulfide bonds that are linked the same way. On the other hand, the amino acid sequence of HNP-4 is longer, and many of the amino acids are different from those in HNP 1-3. It has 33 amino residues, and 19 of the first 30 amino residues are different from those in HNP-1. The molecular weight of HNP-4 is 3710 , and the peptide has a net charge of +4 at neutral $\mathrm{pH}$.

The differences between HNP-4 and HNP 1-3 could indicate that HNP-4 has a special role in neutrophils. Purified HNP-4 was reported to be similar to HNP-1 in activity against gram-positive bacteria and fungi in vitro (19). However, purified HNP-4 was 100-times more bactericidal than HNP-1 when tested against a strain of the gram-negative bacterium Escherichia coli (E. coli). These results could indicate 
that HNP-4 is especially important in the killing of gram-negative bacteria by neutrophils.

HNP-4 is present in small amounts in neutrophils and is difficult to purify. Therefore, there have been few studies on HNP-4 antimicrobial activity. Recently, HNP-4 was chemically synthesized (20). The amino acid sequence was verified by chemical sequencing. The disulfide-bonding pattern was determined using X-ray crystallography and found to be the same as in purified HNP-4 (21).

The availability of synthetic HNP-4 makes it possible to study HNP-4 antimicrobial activity in vitro. However, synthetic HNP-4 was reported to be similar to HNP-1 in bactericidal activity against E. coli (20). Therefore, there is a conflict in the scientific literature about the antimicrobial activity of HNP-4. On the other hand, the study with purified HNP-4 and the study with synthetic HNP-4 used different assay methods and different strains of $E$. coli. These differences may account for differences in results.

\section{Periodontal Pathogens and Defensins}

Periodontal pathogens are types of bacteria that are associated with periodontal disease (22-25). These bacteria are often found in sub-gingival plaque and in periodontal pockets. Many of these periodontal pathogens are gram-negative anaerobic bacteria such as Aggregatibacter (Actinobacillus) actinomycetemcomitans (A.a.), Porphyromonas gingivalis (P.g.), Prevotella intermedia (P.i.), and Fusobacterium nucleatum (F.n.). These gram-negative periodontal pathogens are resistant in vitro to human leukocyte alpha-defensins (HNP-1 or a mixture of HNP 1-3) (26,27). Resistance to neutrophil alpha-defensins may be important in the ability of these bacteria to cause disease. The bacteria survive and grow in an environment where there are high numbers of neutrophils.

Periodontal pathogens are not resistant to all cationic antimicrobial peptides. For example, they are killed by NP-1, a potent alpha-defensin from rabbit neutrophils (28). They are also killed by protegrins $(29,30)$, which are cysteine-rich CAPs from porcine neutrophils. Purified protegrins are undergoing clinical trials as possible oral therapeutic agents $(31,32)$.

If HNP-4 is especially effective in killing gram-negative bacteria including periodontal pathogens, then synthetic HNP-4 might be effective in vivo to prevent or treat periodontal disease. Resistance of periodontal pathogens to HNP-4 has not been studied. Studies may show that periodontal pathogens are resistant to all human alpha-defensins including HNP-4. If they weren't resistant, then they wouldn't be able to survive in sub-gingival plaque and periodontal pockets and wouldn't be able to cause disease. 
It's also possible that the bacteria are resistant to HNP 1-3, but not to HNP-4. The amount of HNP-4 in human neutrophils may be too small to kill or block growth of bacteria in vivo. Therefore, the bacteria may be able to survive in vivo, even though they would be killed if they were exposed to higher concentrations of HNP-4.

\section{Lipopolysaccharide and Gram-negative Bacteria}

Gram-negative bacteria have two unique features. The first is that each cell is surrounded by two membranes. The cell envelope consists of an outer membrane and an inner membrane, with a layer of peptidoglycan in between (Figure 1.2). The presence of lipopolysaccharide (LPS) is the other unique feature of gram-negative bacteria. The outer layer of the outer membrane consists largely of LPS (Figure 1.3). Each cell is covered with about two million molecules of LPS (33).

Besides LPS, a few other substances are exposed on the bacterial cell surface (34). Exposed components include outer membrane proteins, structures such as flagella for motility, pili for DNA transfer, and fimbria for attachment. Some bacteria have an additional S (slime) layer that covers LPS and the cell surface.

LPS is the receptor on the bacterial cell surface for some antimicrobial proteins and peptides. BPI (Bactericidal Permeability Inducing Factor) is a small cationic antimicrobial protein from human neutrophils that binds to LPS and kills many gramnegative bacteria (35). Polymyxin B is an antibiotic produced by the gram-positive bacteria Bacillus polymyxa $(36,37)$. It is a cationic peptide with a lipid attached. Polymyxin B binds to the hydrophobic part of LPS and kills only gram-negative bacteria.

LPS molecules consist of three parts $(33,38)$ : oligosaccharide, core, and lipid A (Figure 1.4). Oligosaccharide is the most exposed part of the LPS on the cell surface. It is responsible for the immune response against specific strains of gram-negative bacteria. Therefore, it is often referred to as the $\mathrm{O}$ antigen. Oligosaccharide is a long polymer of 6-carbon sugars (hexoses) with short hexose branches in a repeating pattern.

The core has two parts: outer and inner core. The outer core is a short polymer of hexoses and a 7-carbon sugar (heptose). The inner core is a polymer containing heptose and the 8-carbon sugar Kdo (3-deoxy-D-manno-octulosonic acid, also known as 2-keto-3-deoxyoctonoic acid). Kdo is found only in LPS. The inner core of LPS can also have phosphate, phosphoryl-ethanolamine, and diphosphoryl-ethanolamine groups.

Lipid A is hydrophobic and holds the LPS molecule in the hydrophobic layer of the outer membrane. Lipid A has two glucosamines, two phosphate groups, and usually six fatty acids. Four of the fatty acids are linked to the glucosamines, and 


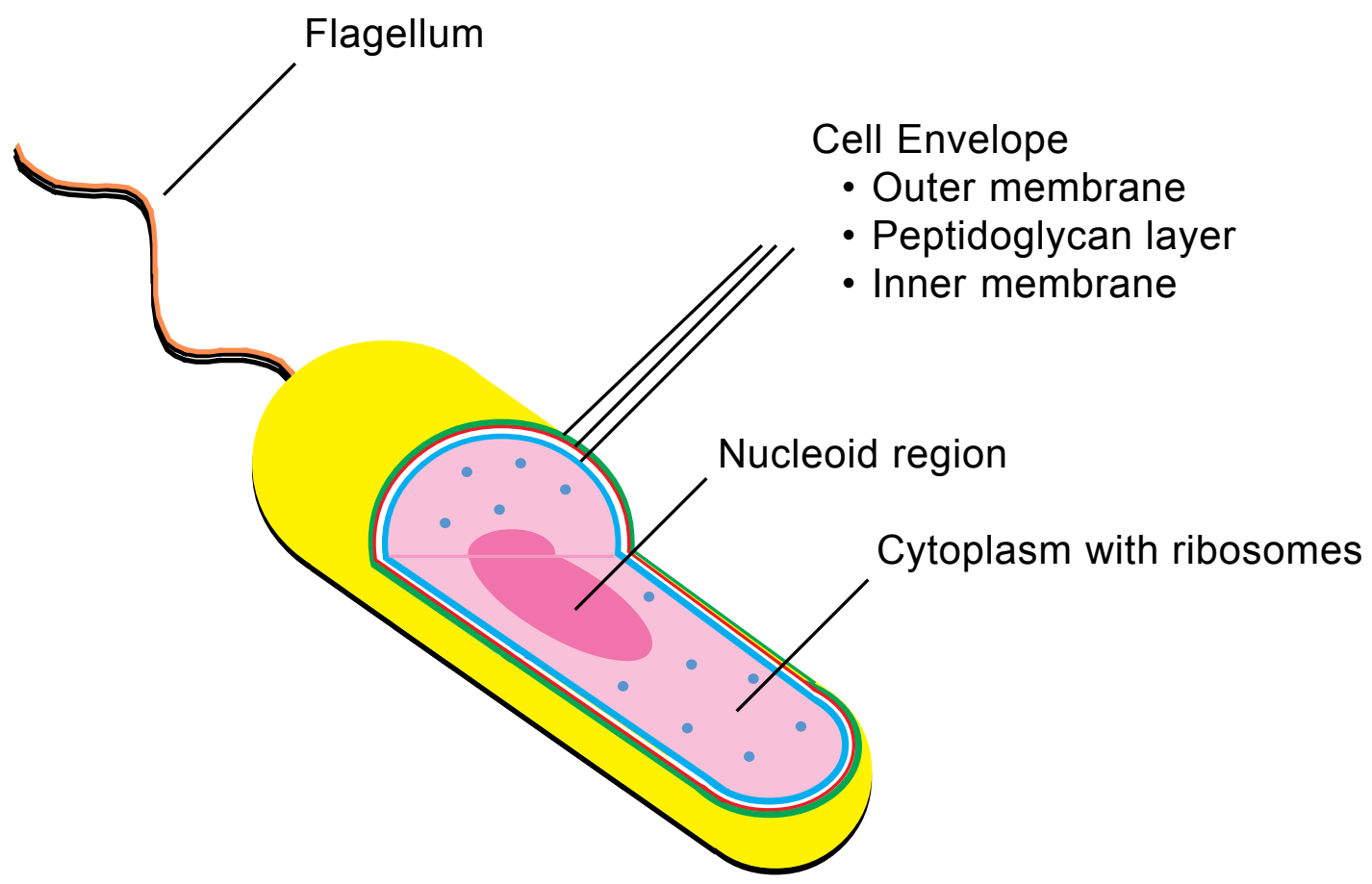

Figure 1.2. Cut-away diagram of a gram-negative bacterium. 


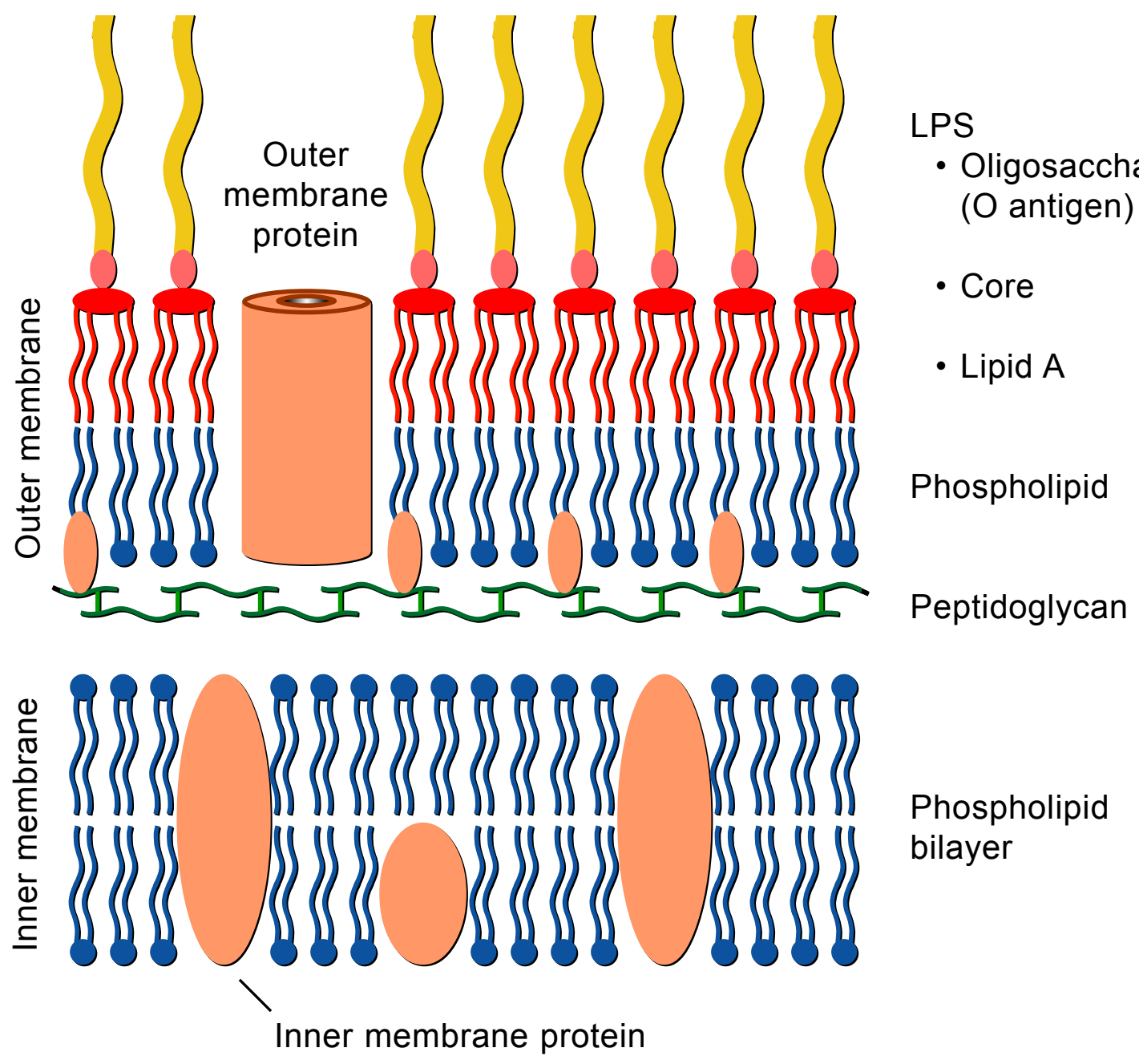

Figure 1.3. Diagram of a section of the gram-negative cell envelope. 
LPS

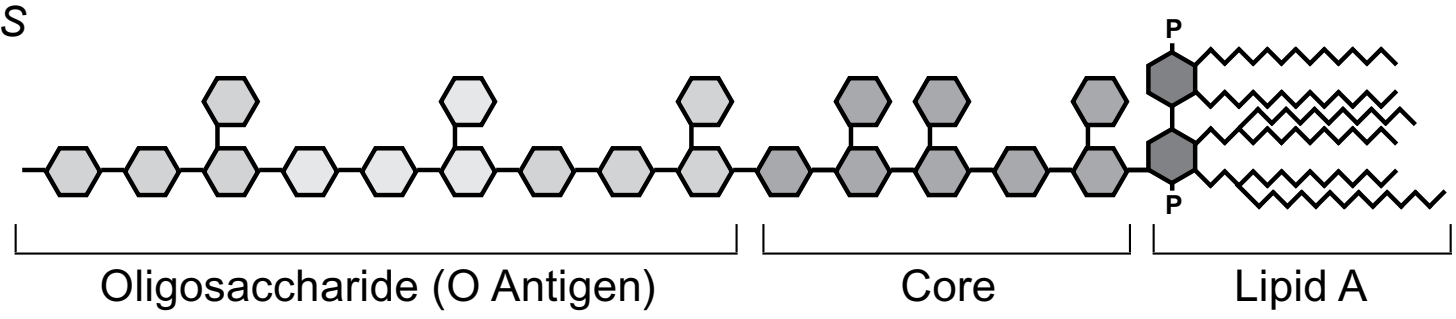

Deacyl-LPS

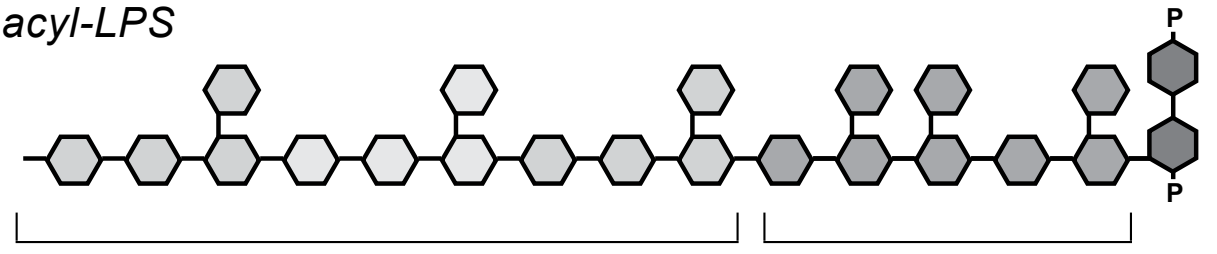

Lipid A

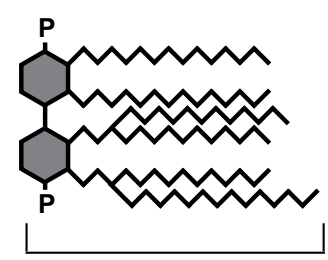

Figure 1.4. Structures of LPS and the deacyl-LPS and lipid A fragments.

Sugars are represented by hexagons, phosphate groups by P, and fatty acids by pleated lines. 
two are linked to hydroxyl groups on beta-hydroxy fatty acids (myristic acid). Lipid $A$ is the part of LPS that has endotoxin activity, which causes fever and septic shock.

Different strains of bacteria can have differences in all three parts of the LPS molecule. For example, there are six known serotypes (a through f) of $A$.a. These serotypes differ in the structure of the oligosaccharide part of LPS. The repeating unit in the oligosaccharide part of LPS of each of the six strains has been determined $(39-41)$.

Some bacteria lack the oligosaccharide part of LPS. Examples are the K12 strains of E. coli. Bacteria that lack oligosaccharide have a "rough" colony morphology that differs from the "smooth" morphology of most gram-negative bacteria. Rough strains are more sensitive than smooth strains to killing by polymyxin B (42), probably because it is easier for polymyxin to enter the LPS layer and bind to lipid A when there is no oligosaccharide. A K12 strain of E. coli was used in the study by Wilde et al. (19), which reported that purified HNP-4 was especially effective against E. coli.

The structure of the core has been determined for K12 strains of E. coli. (Figure 1.5). Differences in the core structure have been reported for other strains of $E$. coli and salmonella strains. For example, some strains lack the third Kdo unit. However, the inner core structure shown in Figure 1.5 is highly conserved in enteric bacteria $(33,38)$.

The structure of the lipid A part of LPS has been determined for many types of gram-negative bacteria because lipid A is the part of LPS that has immunoregulatory activity and endotoxin activity (33). There is only a small difference in the lipid A of $E$. coli and A.a. The E. coli lipid A has five 14-carbon fatty acids and one 12-carbon fatty acid. The A.a. LPS has six 14-carbon fatty acids (43).

Some periodontal pathogens such as P.g. and P.i. have lipid A structures that are different from the lipid A of A.a. or E. coli $(44,45)$. The lipid A part of LPS preparations from these organisms have one rather than two phosphates. They have only three or five fatty acids, and some of the fatty acids have methyl branches. The LPS or lipid A from these organisms has less endotoxin activity, probably as a result of these differences in structure $(46,47)$. 

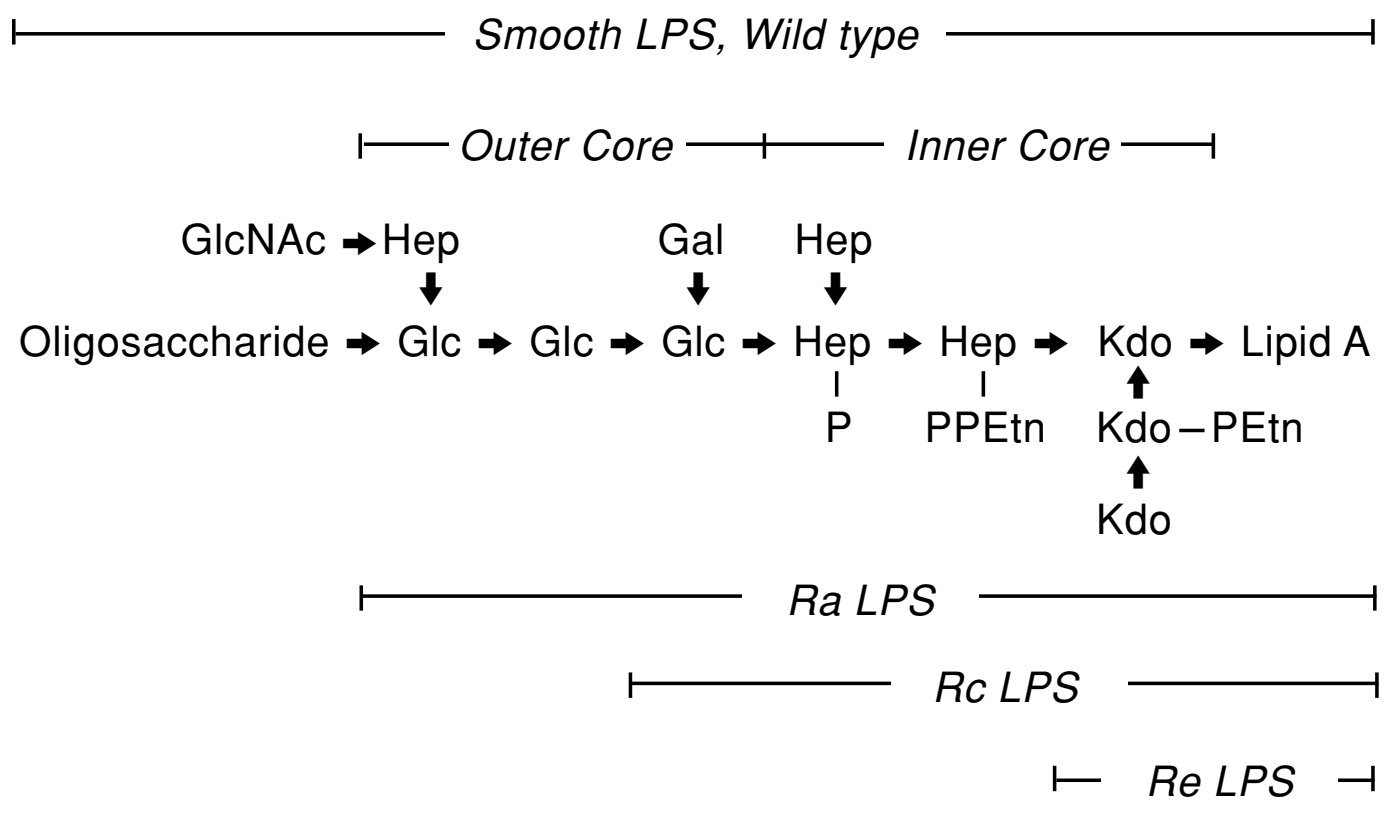

Figure 1.5. Structures of $E$. coli LPS and LPS from rough (R) mutants. Oligosaccharide is a polymer of hexoses. The outer core contains the hexoses glucose (Glc), galactose (Gal), and N-acetyl-glucosamine (GlcNac), and a heptose (Hep). The inner core contains heptose (Hep) and Kdo with phosphate (P) and phosphoryl- or pyrophosphoryl-ethanolamine (P-Etn or PP-Etn). The structure of lipid A is shown in Figure 1.4. 


\section{CHAPTER 2. SPECIFIC OBJECTIVES}

The general objectives are to determine: (a) Whether HNP-4 differs from the other human neutrophil alpha-defensins in killing gram-negative bacteria including E. coli and the periodontal pathogen A.a. (b) Whether LPS on the surface of gramnegative bacteria could be the receptor that binds HNP-4.

The first objective is to use mass spectrometry to compare the purity and physical properties of synthetic HNP-4 and HNP-4 purified from human leukocytes. The aim is to determine whether there are any differences between synthetic and purified HNP-4 that could cause them to have different antimicrobial activity.

The second objective is to compare the antibacterial activity of synthetic and purified HNP-4 against the standard test organism E. coli ML-35 under standard assay conditions. The aims are to determine if there is any difference in antibacterial activity of synthetic and purified HNP-4 and whether HNP-4 is especially effective in killing gram-negative bacteria.

The third objective is to determine whether HNP-4 binds to purified LPS from E. coli. Purified LPS will be added to mixtures of HNP-4 and E. coli ML-35 to determine whether the purified LPS absorbs HNP-4 and blocks killing of E. coli. If purified LPS blocks killing, then blocking gives an indirect method of measuring binding of HNP-4 to LPS. The aim is to determine whether HNP-4 binds to LPS. If so, this result could indicate that LPS is the receptor for HNP-4 on the cell surface of gram-negative bacteria.

The fourth objective is to compare the binding of HNP-4 to LPS fragments. If the results show that LPS could be the receptor for HNP-4 on the cell surface, LPS fragments that lack parts of the complete LPS structure will be added to mixtures of HNP-4 and E. coli ML-35 to determine whether the fragments absorb HNP-4 and block killing of E. coli. The aim is to identify the part of the LPS molecule that acts as the receptor for HNP-4. If the results indicate that HNP-4 binds to oligosaccharide, then HNP-4 may bind better to oligosaccharides that have a particular arrangement of hexoses. Therefore, killing of A. $a$. and other pathogens may be strain-specific. If the results indicate that HNP-4 binds to the core, HNP-4 may be more effective against "rough" strains without oligosaccharide than against "smooth" strains. If the results indicate that HNP-4 binds to lipid A, then differences in the lipid A structures of periodontal pathogens might make HNP-4 able to kill some types of periodontal pathogens but not others.

The fifth objective is to measure the antibacterial activity of HNP-4 against the periodontal pathogen A.a. in vitro. The aim is to determine whether A.a. is resistant to all the human leukocyte alpha-defensins or whether HNP-4 is more effective than HNP 1-3 against this gram-negative periodontal pathogen. 
The sixth objective is to compare the binding of HNP-4 to LPS purified from E. coli and from A.a. Various amounts of E. coli or A.a. LPS will be added to mixtures of HNP-4 and E. coli ML-35 to determine whether the purified LPS absorbs HNP-4 and blocks killing of $E$. coli. This will give an indirect method of comparing binding of HNP-4 to the two types of LPS. The aim is to determine whether there is a difference in binding of HNP-4 to LPS from E. coli or A.a. If LPS is the receptor for HNP-4, and HNP-4 kills both E. coli and A.a., then HNP-4 should bind to purified LPS from E. coli or A.a. On the other hand, if A.a. is resistant to HNP-4, then HNP-4 may bind to E. coli LPS but not to A.a. LPS. 


\section{CHAPTER 3. MATERIALS AND METHODS}

\section{Materials}

\section{Chemicals}

Bovine serum albumin, trifluoroacetic acid (TFA), acetonitrile, and sinapinic acid were from Sigma Aldrich Chemical Co., St. Louis, MO. Sodium bicarbonate, triethylamine, and hydrochloric acid were from Fisher Scientific, Pittsburgh, PA. Allin-1 peptide and protein standards were from Ciphergen Biosystems, Freemont, CA. Bacto-agar and Trypticase Soy Broth (TSB) were from Becton Dickinson, Sparks, MD.

\section{Antimicrobial Peptides}

Polymyxin B was from Sigma Aldrich Chemical Co.

HNP-4 and a mixture of HNP 1-3 were purified from a 10\% acetic acid extract of human neutrophil granules by modifications of the methods of Wilde et al. (19) and Ganz et al. (17) in the laboratory of Dr. Thomas at the UTHSC College of Dentistry. The yields of purified HNP-4 and HNP 1-3 from $200 \mathrm{mg}$ of granule protein were 0.17 $\mathrm{mg}$ and $13.7 \mathrm{mg}$, respectively, or $0.1 \%$ and $7 \%$.

HNP-1 was purified from the mixture of HNP 1-3 by the method of Ganz et al. (17) in the laboratory of Dr. Thomas at the UTHSC College of Dentistry. The protein concentrations of purified HNP-1 and HNP-4 were determined by the method of Lowry et al. (48) with bovine serum albumin as the standard.

Synthetic HNP-4 (20) was provided by Dr. W. Lu at the University of Maryland Biotechnology Institute. Synthetic HNP-4 (1.67 mg) was dissolved in $1.5 \mathrm{~mL} 0.01 \%$ acetic acid to give a $300 \mu \mathrm{M}$ solution, assuming a molecular weight of 3710 . The $300 \mu \mathrm{M}$ synthetic HNP-4 solution was assayed using the protein determination method of Lowry et al. (48) with bovine serum albumin as the standard and was found to give the expected concentration. Solutions of $100 \mu \mathrm{M} \mathrm{HNP}-4$ and $10 \mu \mathrm{M}$ HNP-4 were prepared by dilution of the $300 \mu \mathrm{M}$ solution in $0.01 \%$ acetic acid.

\section{LPS and LPS Fragments}

LPS from E. coli of serotype O111:B4 was purchased from List Biological Laboratories, Campbell, CA. Rough LPS (Ra) from E. coli EH100 was purchased from Sigma Aldrich Chemical Co. Rough LPS (Rc) from E. coli J5 and rough LPS (Re) from E. coli K12-D31m4 were purchased from List Biological Laboratories. 
A.a. LPS was purified from the Y4 strain in the laboratory of Dr. Jegdish Babu at the UTHSC College of Dentistry using the method of Millar et al. (49) in which LPS is extracted from an outer membrane fraction (50) by the hot water-phenol method of Westphal and Jann (51).

Deacylated (detoxified) LPS (deacyl-LPS), prepared by alkaline hydrolysis (52) of LPS from E. coli serotype O111:B4, was purchased from Sigma Aldrich Chemical Co. Lipid A (diphosphoryl) prepared (53) from LPS of the rough (Re) mutant E. coli K12-D31m4 was purchased from List Biological Laboratories Inc. Kdo2-lipid A (Di[3-deoxy-D-manno-octulosonyl]-lipid A) (ammonium salt) was purchased from Avanti Polar Lipids Inc., Alabaster, AL.

LPS, deacyl-LPS and Kdo2-lipid A were dispersed in water or $10 \mathrm{mM}$ potassium phosphate $\mathrm{pH} 7.4$ buffer by incubating $5 \mathrm{~min}$ in a sonicator bath at $25^{\circ} \mathrm{C}$. Lipid A was solubilized with triethylamine by the procedure of Tanamoto et al. (54).

\section{Bacteria}

E. coli of serotype O111:B4, a smooth strain with well-characterized LPS, was obtained from Dr. Peter G. Eichaker and Dr. Steven Richmond at the Critical Care Medicine Department of the National Institutes of Health, Bethesda, MD. All other bacterial strains were obtained from the American Type Culture Collection (ATCC), Manassas, VA. E. coli ML-35 (ATCC 43827) was used as the standard test organism for measuring defensin activity. E. coli J5 (ATCC 43745) is a rough (Rc) mutant that lacks oligosaccharide and most of the core. The Y4 strain of A.a. (ATCC 43718) is serotype b.

\section{Methods}

\section{Bacterial Inocula}

E. coli ML-35 bacteria were grown to early stationary phase in Medium AGlucose $(0.06 \mathrm{M}$ potassium phosphate, $1.7 \mathrm{mM}$ sodium citrate, $7.6 \mathrm{mM}$ ammonium sulfate, $0.014 \mathrm{mM}$ magnesium sulfate, $20 \mathrm{mM}$ glucose) (55). All other bacteria were grown as indicated below in filter-sterilized Trypticase Soy Broth (TSB). Portions $(1.5 \mathrm{~mL})$ of the bacterial cultures were frozen at $-80^{\circ} \mathrm{C}$. The frozen cultures were used to inoculate cultures for experiments.

\section{Bacterial Cultures}

An inoculum was thawed and a $1 \mathrm{~mL}$ portion was added to $100 \mathrm{~mL}$ of TSB. $E$. coli strains were grown for $16 \mathrm{~h}$ to stationary phase in foam-stoppered flasks at 
$37^{\circ} \mathrm{C}$ with continuous mixing for aeration in an rotary shaker. A.a. Y4 was grown for $24 \mathrm{~h}$ to stationary phase at $37^{\circ} \mathrm{C}$ with continuous mixing in sealed $100 \mathrm{~mL}$ bottles to restrict aeration. Media for both liquid and solid cultures of A.a. were sterilized by ultrafiltration through $0.4 \mu$ nitrocellulose filters (Nalgene Co., Rochester, NY). Media for liquid cultures of $E$. coli were sterilized by ultrafiltration, and media for solid-phase culture of $E$. coli were sterilized by autoclaving.

For experiments with $E$. coli, the bacteria in a $10 \mathrm{~mL}$ portion of a stationary phase culture were collected and washed twice by centrifugation at $17,000 \mathrm{x} \mathrm{g}$ for $12 \mathrm{~min}$ at $4^{\circ} \mathrm{C}$ with $10 \mathrm{mM}$ potassium phosphate $\mathrm{pH} 7.4$ buffer. The washed bacteria were suspended in $10 \mathrm{mM}$ potassium phosphate buffer to an optical density of 0.6 at 600 $\mathrm{nm}$ to give $2 \times 10^{8}$ colony forming units $(\mathrm{CFU}) / \mathrm{mL}$.

For experiments with A.a., a portion of a $24 \mathrm{~h}$ culture was diluted 5 fold to $1 \mathrm{x}$ $10^{8} \mathrm{CFU} / \mathrm{mL}$ with $10 \mathrm{mM}$ phosphate buffer at $25^{\circ} \mathrm{C}$ and used immediately.

\section{Antibacterial Assay}

Bacteria $\left(10^{6} \mathrm{CFU} / \mathrm{mL}\right)$ in $100 \mu \mathrm{L}$ total volume (E. coli) or $200 \mu \mathrm{L}$ total volume (A.a.) were incubated with gentle mixing in $1 \% \mathrm{TSB}$ with $10 \mathrm{mM}$ potassium phosphate $\mathrm{pH} 7.4$ buffer. Antimicrobial peptides and LPS were added in various concentrations as indicated for each experiment. Incubation mixtures with E. coli were incubated $4 \mathrm{~h}$ at $37^{\circ} \mathrm{C}$ aerobically in $1.8 \mathrm{~mL}$ polypropylene vials. Incubation mixtures with A.a. were incubated $4 \mathrm{~h}$ at $37^{\circ} \mathrm{C}$ in a 96 -well plate that was placed inside a BBL ${ }^{\text {TM }}$ GasPak Pouch ${ }^{\text {TM }}$ Anaerobic System to lower the oxygen $\left(\mathrm{O}_{2}\right)$ concentration and raise the carbon dioxide $\left(\mathrm{CO}_{2}\right)$ concentration. At the end of the incubation, the number of viable bacteria was determined by making serial 1:10 dilutions in sterile $10 \mathrm{mM}$ phosphate $\mathrm{pH} 7.4$ buffer, plating $0.8 \mathrm{~mL}$ portions of the dilutions on solid growth medium (TSB/2\% agar), and counting bacterial colonies after 1 to 2 days at $37^{\circ} \mathrm{C}$. E. coli bacteria on solid media were incubated under air at $37^{\circ} \mathrm{C}$. A.a. bacteria on solid media were incubated under $95 \%$ air $/ 5 \% \mathrm{CO}_{2}$ at $37^{\circ} \mathrm{C}$. The number of viable bacteria/mL in the incubation mixture was calculated.

\section{MALDI-TOF Mass Spectrometry}

MALDI-TOF mass spectrometry was used to compare the molecular weight of synthetic and purified HNP-4 and to evaluate the purity of the preparations. Mass spectra in the range of 2,000 to 10,000 were obtained with a Ciphergen Biosystem PBSII mass spectrometer calibrated with All-in-1 peptide standard. Standards and samples were mixed 1:1 with a saturated sinapinic acid solution in $50 \%$ acetonitrile with $0.5 \%$ TFA. Each sample $(1 \mu \mathrm{L})$ was applied to two positions on a gold metal chip (Ciphergen Biosystems). Synthetic HNP-4 was applied at 25 pmoles per spot. 
Samples were air-dried, and mass spectra were obtained. Average spectra were obtained from 80 laser shots at 20 positions distributed across the sample.

Mass spectra of the samples were also obtained in the molecular weight range from 10,000 to 100,000 Da with the PBSII mass spectrometer calibrated with All-in-1 protein standard.

\section{Estimated Molecular Weights of LPS and Fragments}

Molecular weights were estimated or calculated for LPS and LPS fragments so that the number of molecules needed to block killing by HNP-4 could be determined. Molecular weights used to calculate concentrations of LPS preparations are listed in Table 3.1.

All LPS preparations are heterogeneous due to variation in the number of repeating units in the oligosaccharide part and varying amounts of substitution on heptose and Kdo units in the core. An average molecular weight of 10,000 Da was reported for LPS of E. coli serotype O111:B4 (56) and was used in calculations in this study. Because no estimates for the molecular weight of LPS from the A.a. Y4 strain were found, the same value of 10,000 Da was used.

Figure 1.4 shows schematic representations of the structure of LPS, deacyl LPS, and lipid A fragments. Based on the structure, a molecular weight of 8,704 was calculated for deacylated LPS. The molecular weights of one 12-carbon fatty acid [200], one 14-carbon fatty acid [228], and four 14-carbon beta-hydroxy fatty acids [4 $\mathrm{x} 244]$ were subtracted from 10,000, and the molecular weight of 6 water molecules [6 x 18] was added.

Diagrams of the structures of LPS from rough mutants of E. coli K12 strains are shown in Figure 1.5. A molecular weight of 4,442 was calculated for E. coli Ra LPS from the molecular weight of 2,663 calculated for the structure of the K12 core $(33,38)$ plus the molecular weight of 1,797 that was calculated for the structure of E. coli lipid A, minus the molecular weight of one water molecule. Molecular weights of 3,733 and 2,660 were calculated for E. coli Rc and Re LPS from the structures shown in Figure 1.5.

\section{Data Analysis}

All experiments were performed at least twice with duplicate samples. Statistical significance was evaluated by Analysis of Variance (ANOVA) followed by Scheffe's $f$ test to calculate $p$ values using StatView 5.0 software. Values less than 0.05 were considered significant. 
Table 3.1. Average molecular weights of LPS preparations.

\begin{tabular}{lc}
\hline \multicolumn{1}{c}{ LPS preparation } & Average molecular weight (Da) \\
\hline LPS from E. coli of serotype O111:B4 & 10,000 \\
LPS from A.a. Y4 (serotype b) & 10,000 \\
Deacyl-LPS from E. coli of serotype O111:B4 & 8,704 \\
Ra LPS from E. coli EH100 & 4,442 \\
Rc LPS from E. coli J5 & 3,733 \\
Re LPS from E. coli K12-D31m4 & 2,660 \\
Kdo2-lipid A (ammonium salt) & 2,307 \\
Diphosphoryl lipid A & 1,797 \\
\hline
\end{tabular}




\section{CHAPTER 4. RESULTS}

\section{Physical Properties of Synthetic and Purified HNP-4}

\section{MALDI-TOF Mass Spectrometry}

The goals of these experiments were to determine whether there are any differences between synthetic HNP-4 and purified HNP-4 that could cause them to have different antimicrobial activity. MALDI-TOF mass spectrometry was used to compare the molecular weights of synthetic and purified HNP-4 and to evaluate the purity of the synthetic and purified HNP-4 preparations.

Mass spectra of the Ciphergen All-in-1 standards, synthetic HNP-4, and purified HNP-4 were measured in the range of 2,000 to 10,000 Da (Figure 4.1). The first spectrum in Figure 4.1 is that of the All-in-1 peptide standard. The instrument was calibrated using the masses of 3469, 5808, and 7034 Da for bovine insulin B chain, human insulin $\mathrm{A}+\mathrm{B}$ chains, and hirudin BHVK. The second and third spectra in Figure 4.1 are of purified and synthetic HNP-4. Purified and synthetic HNP-4 each had a single major peak at 3711 Da. The purified HNP-4 preparation contained a very minor contaminant with a mass of $4396 \mathrm{Da}$.

Minor peaks below and above the major peak were seen with both synthetic and purified HNP-4. These minor peaks are often seen in mass spectra of peptides when sinapinic acid is used as the energy absorbing matrix. A small peak was visible in both preparations at $7422 \mathrm{Da}$, twice the molecular weight of the HNP-4, and is probably a dimer of HNP-4.

Figure 4.2 shows the mass spectra expanded to show only the 3400 to $3800 \mathrm{Da}$ range, the region of the HNP-4 peak. The purified and synthetic HNP-4 preparations each had peaks at $3711 \mathrm{Da}$. The calculated molecular mass for HNP-4 is $3710 \mathrm{Da}$. The calculated and observed values are identical within the instrument accuracy of $0.1 \%$ for externally calibrated samples.

Mass spectra of the samples were also obtained in the molecular weight range from 10,000 to $100,000 \mathrm{Da}$ (not shown). No proteins were detected.

These results indicate that there was no difference in the molecular mass of the synthetic and purified HNP-4 and that the synthetic and purified HNP-4 preparations were of high purity. 


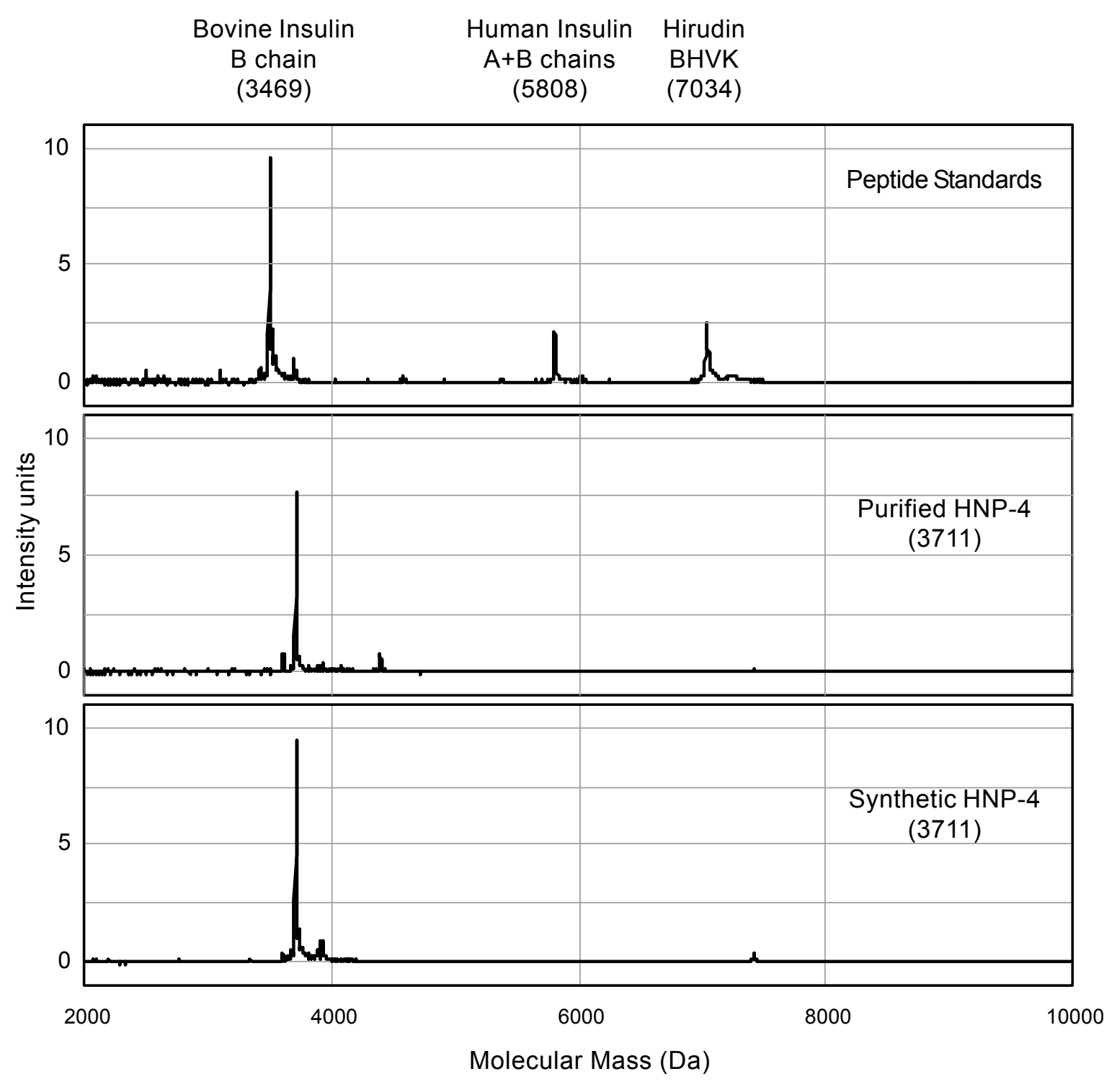

Figure 4.1. Purity of the HNP-4 preparations.

MALDI-TOF mass spectrometry was used to compare the purity of purified and synthetic HNP-4 preparations in the molecular weight range from 2,000 to 10,000 Da. Top: Peptide standards (All-in-1 peptide standards) were used to calibrate the mass spectrometer. Middle: Purified HNP-4. Bottom: Synthetic HNP-4. 


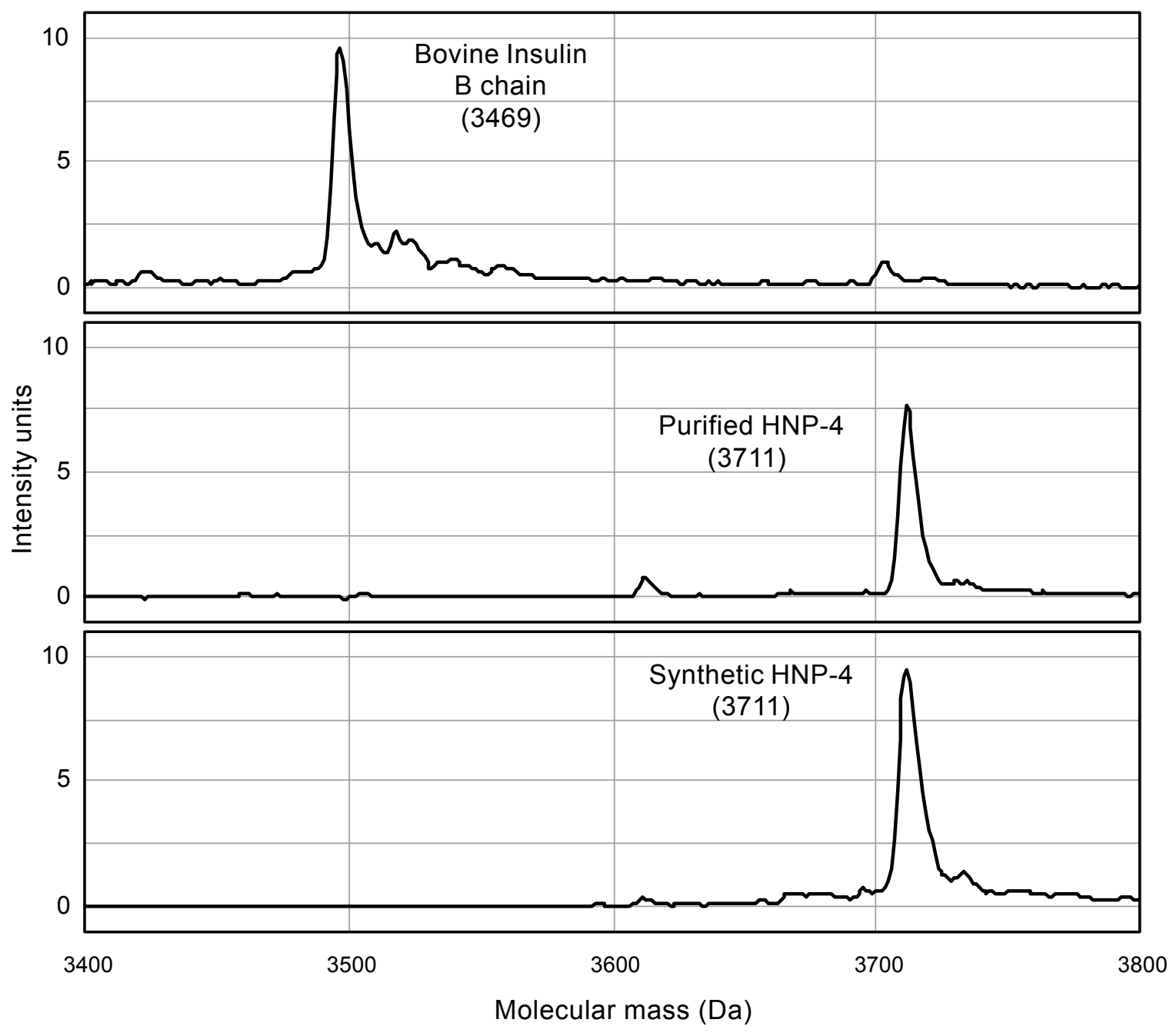

Figure 4.2. Molecular mass of purified and synthetic HNP-4.

MALDI-TOF mass spectrometry was used to compare the molecular weight of purified and synthetic HNP-4. Top: The peptide standard bovine insulin B chain. Middle: Purified HNP-4. Bottom: Synthetic HNP-4. 


\section{Extinction Coefficient}

The amount of light absorbed by a solution of a particular protein depends on the protein concentration and the amino acid composition of the protein. Therefore, measuring the absorbance of a HNP-4 solution provides a way to determine the protein concentration, whether the HNP-4 has the expected amino acid composition, and whether the solution contains protein contaminants.

To characterize the $300 \mu \mathrm{M}$ synthetic HNP-4 solution that was prepared by dissolving a known weight of HNP-4 in a known volume, the absorbance at $278 \mathrm{~nm}$ was measured and found to be 0.413 . Based on this absorbance, the molar extinction coefficient of synthetic HNP-4 at $278 \mathrm{~nm}$ is 1,377. This value is close to the value of 1,400 that was calculated for the HNP-4 protein sequence with the on-line Protein Calculator v3.3 software provided by Chris Putnam of Scripps Research Institute $<$ www.scripps.edu/ cdputnam/protcalc.html $>$. This calculation is based on the absorption of aromatic amino residues using equations based on the method of Gill and Von Hippel (58). The molar extinction coefficient of 1,377 for HNP-4 is much lower than the value of 9,800 that was calculated for HNP-1 at $278 \mathrm{~nm}$. HNP-4 has one uv-absorbing amino acid residue, tyrosine (Y), but HNP-1 has one tryptophan (W) and three tyrosine (Y) residues. This observation provides more evidence that the synthetic HNP-4 had the correct amino acid composition and was of high purity.

Because the volume of the HNP-4 preparation from human neutrophils was small, it wasn't possible to determine the extinction coefficient of purified HNP-4.

However, the column fractions that were combined and concentrated to obtain HNP-4 had a low $280 \mathrm{~nm}$ absorbance compared with the protein concentration that was measured for the purified HNP-4. This result is consistent with isolation of a peptide with a low extinction coefficient and no contaminating proteins or peptides.

\section{Activity of Synthetic and Purified HNP-4 against $E$. coli}

\section{Killing of $E$. coli ML-35 by Synthetic HNP-4}

The goals of this experiment were to determine whether synthetic HNP-4 kills E. coli ML-35 and whether very low concentrations of HNP-4 are enough to kill. The ML-35 strain of $E$. coli is the standard test organism for measuring alpha-defensin activity. These bacteria are killed by human leukocyte defensin HNP-1, -2, or -3 (17).

Washed bacteria $\left(10^{6} \mathrm{CFU} / \mathrm{ml}\right)$ were diluted and plated immediately or incubated $4 \mathrm{~h}$ at $37^{\circ} \mathrm{C}$ with various concentrations of synthetic HNP-4 from 0 to $30 \mu \mathrm{M}$ in dilute growth medium (1\% TSB) with $10 \mathrm{mM}$ phosphate buffer. At the end of the incubation, the number of viable organisms was determined by diluting, plating, and counting colonies. 
Figure 4.3 shows that when HNP-4 was not added, the bacteria grew during the 4 $\mathrm{h}$ incubation. The number of colony-forming units increased almost 100-fold. Adding $3 \mu \mathrm{M} \mathrm{HNP}-4$ partially inhibited growth. Adding $5 \mu \mathrm{M}$ HNP-4 blocked growth and caused about a $90 \%$ decrease in the number of viable bacteria below the starting level of $10^{6} \mathrm{CFU} / \mathrm{ml}$. Adding $10 \mu \mathrm{M}$ HNP-4 caused nearly a 100 -fold decrease in the number of viable bacteria, and $30 \mu \mathrm{M}$ HNP-4 caused a 1000-fold decrease. The lowest concentration of HNP-4 that consistently killed about $99 \%$ of the bacteria was $10 \mu \mathrm{M}$. This concentration of HNP-4 $(10 \mu \mathrm{M})$ was chosen as the concentration to be used in later experiments.

The results show that synthetic HNP-4 killed E. coli ML-35. However, the HNP-4 concentration needed was not especially low. In other experiments (not shown), purified $5 \mu \mathrm{M}$ HNP-1 caused $99.7 \pm 0.1 \%$ killing of $E$. coli ML-35. Therefore, HNP-4 was not more active than HNP-1 when tested under these conditions. Instead, HNP-4 was about half as active as HNP-1.

Our results with HNP-1 were consistent with results from other laboratories. Previous studies of the activity of human neutrophil defensins against $E$. coli used 15 $\mu \mathrm{M}$ HNP-1 or a HNP 1-3 mixture (17), 6 to $9 \mu \mathrm{M}$ HNP-1 (26), or $7 \mu \mathrm{M}$ synthetic HNP-1 (20) to kill $99 \%$ of the bacteria.

\section{Killing of E. coli ML-35 by Purified HNP-4}

To determine whether HNP-4 purified from human neutrophils is more effective than synthetic HNP-4, killing of E. coli ML-35 by purified HNP-4 was measured under the experimental conditions described above. The experiment was not performed in duplicate because only a small amount of HNP-4 was available. The results with HNP-4 purified from human neutrophils were similar to those with synthetic HNP-4. Purified HNP-4 at 1 or $3 \mu \mathrm{M}$ had no effect, but $10 \mu \mathrm{M}$ purified HNP-4 killed 99\% of the bacteria (data not shown). Therefore, when tested under the same conditions against the standard test gram negative organism, synthetic and purified HNP-4 had equal activity.

Because very little purified HNP-4 was available, all further experiments were performed with synthetic HNP-4.

\section{Killing of $E$. coli Serotype O111:B4 by Synthetic HNP-4}

LPS from E. coli serotype O111:B4 is commercially available and has been used in many published studies of LPS. Therefore, LPS from E. coli serotype O111:B4 was used in this study as an example of LPS purified from an HNP-4 sensitive organism. Experiments similar to those described above were performed to confirm that $E$. coli O111:B4 is killed by HNP-4. Figure 4.4 shows that E. coli serotype 


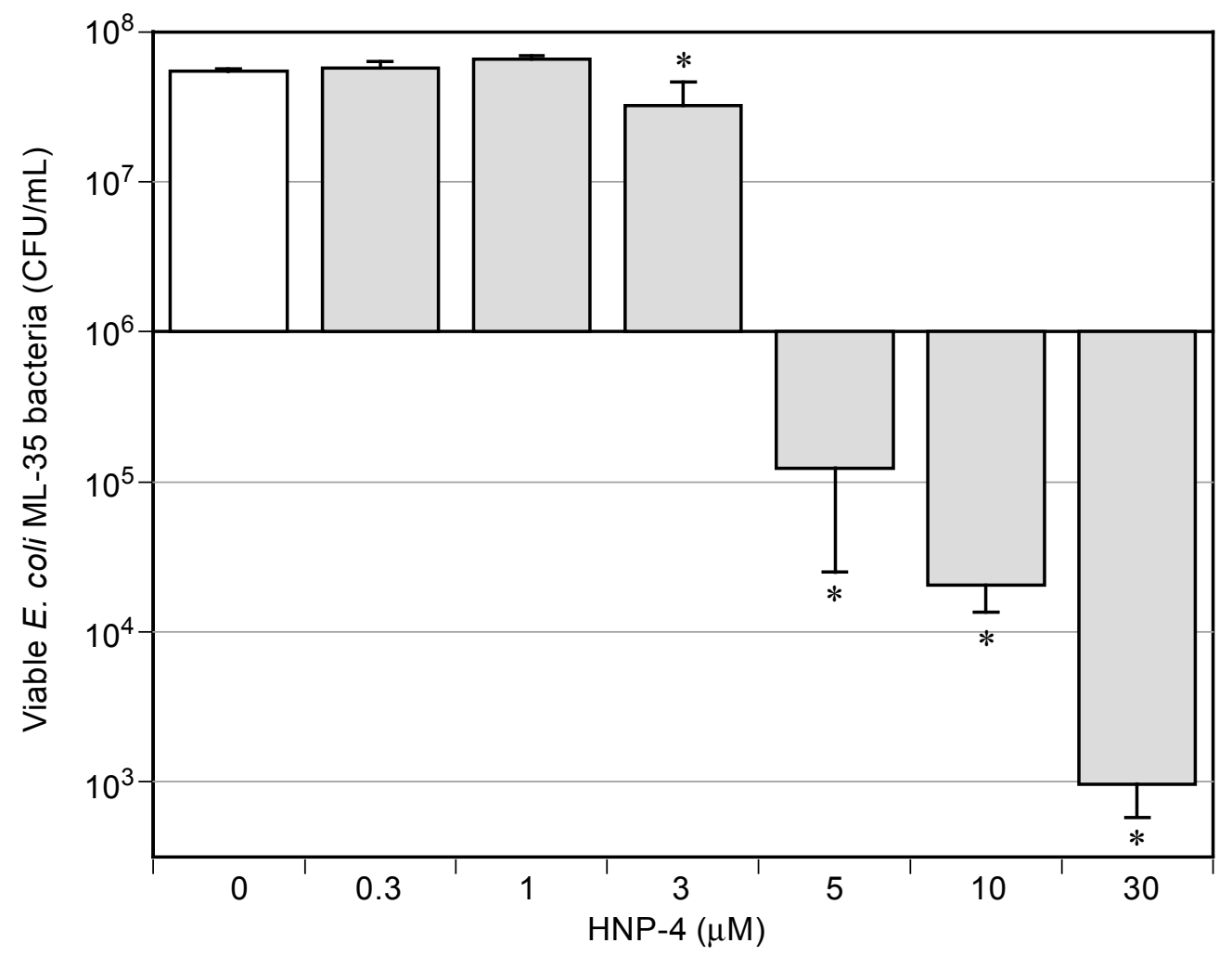

\begin{tabular}{lccrr} 
Conditions & $\begin{array}{c}\text { Viable bacteria } \\
\left(10^{6} \mathrm{CFU} / \mathrm{ml}\right)\end{array}$ & S.E. & $\mathrm{n}$ & P Value \\
\hline Control $\left(4 \mathrm{~h}, 37^{\circ} \mathrm{C}\right)$ & 54.446 & 2.615 & 30 & - \\
HNP-4, $0.3 \mu \mathrm{M}$ & 57.189 & 6.394 & 3 & 1.0 \\
HNP-4, $1 \mu \mathrm{M}$ & 65.424 & 3.336 & 7 & 0.6 \\
HNP-4, $3 \mu \mathrm{M}$ & 32.143 & 14.008 & 5 & $0.03^{*}$ \\
HNP-4, $5 \mu \mathrm{M}$ & 0.122 & 0.097 & 5 & $<0.0001^{*}$ \\
HNP-4, $10 \mu \mathrm{M}$ & 0.020 & 0.007 & 26 & $<0.0001^{*}$ \\
HNP-4, $30 \mu \mathrm{M}$ & 0.001 & 0.000 & 4 & $<0.0001^{*}$
\end{tabular}

* Significantly different from the control value without HNP-4.

Figure 4.3. Synthetic HNP-4 kills E. coli ML-35.

E. coli ML-35 bacteria $\left(10^{6} / \mathrm{ml}\right)$ were incubated $4 \mathrm{~h}$ at $37^{\circ} \mathrm{C}$ without HNP-4 (control; white bar) or with 0.3 to $30 \mu \mathrm{M} \mathrm{HNP}-4$ (gray bars). Values shown on the logarithmic scale in the bar graph are shown in linear form in the table below the graph. 


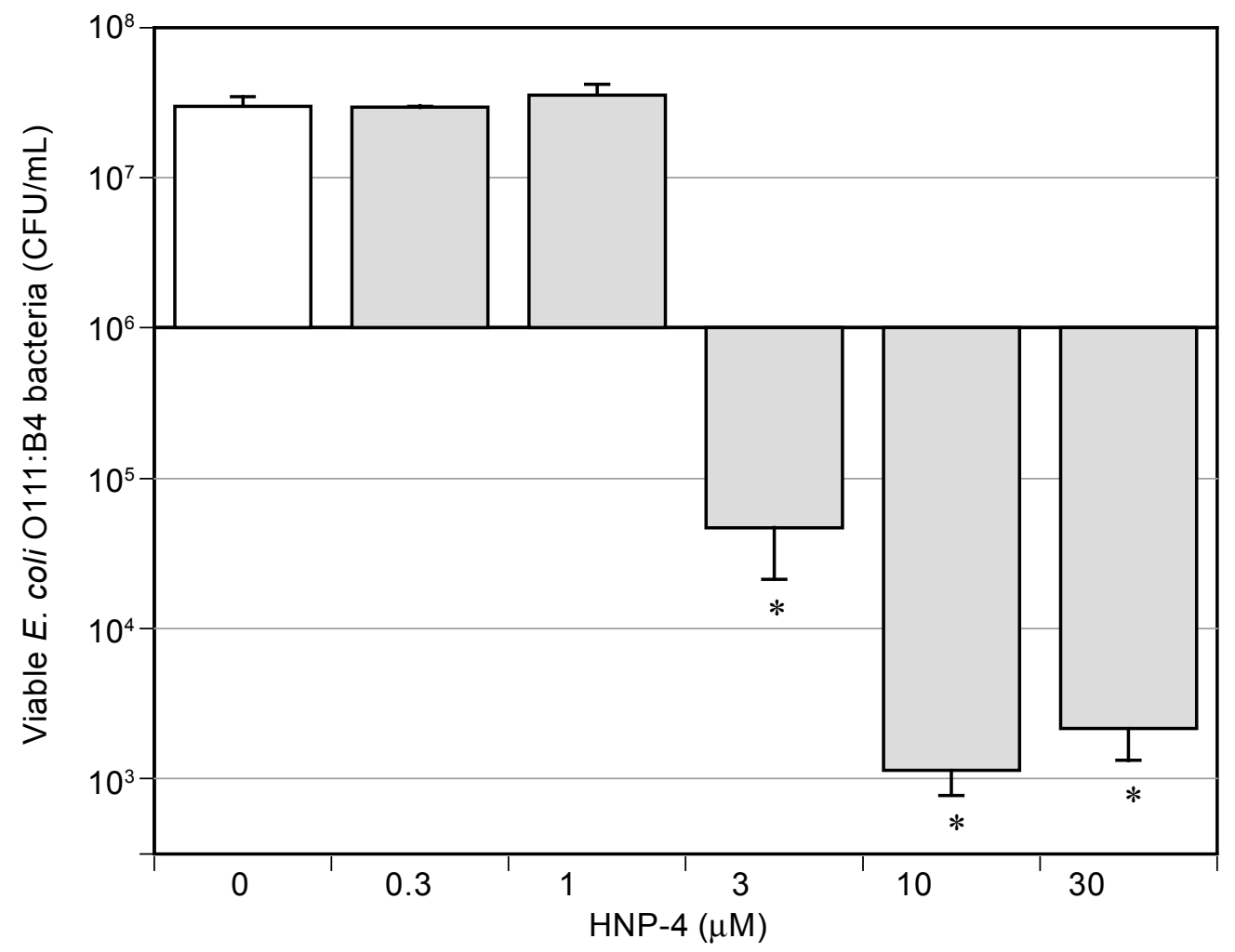

\begin{tabular}{lcccr} 
Conditions & $\begin{array}{c}\text { Viable bacteria } \\
\left(10^{6} \mathrm{CFU} / \mathrm{ml}\right)\end{array}$ & S.E. & $\mathrm{n}$ & P Value \\
\hline Control $\left(4 \mathrm{~h}, 37^{\circ} \mathrm{C}\right)$ & 30.137 & 4.566 & 2 & - \\
$\mathrm{HNP}-4,0.3 \mu \mathrm{M}$ & 29.224 & 0.913 & 2 & 1.0 \\
$\mathrm{HNP}-4,1 \mu \mathrm{M}$ & 35.616 & 6.393 & 2 & 0.9 \\
$\mathrm{HNP}-4,3 \mu \mathrm{M}$ & 0.047 & 0.026 & 2 & $0.01^{*}$ \\
$\mathrm{HNP}-4,5 \mu \mathrm{M}$ & 0.001 & 0.000 & 2 & $0.01^{*}$ \\
$\mathrm{HNP}-4,10 \mu \mathrm{M}$ & 0.002 & 0.001 & 2 & $0.01^{*}$
\end{tabular}

* Significantly different from the control value without HNP-4.

Figure 4.4. Synthetic HNP-4 kills E. coli of serotype O111:B4.

E. coli bacteria $\left(10^{6} / \mathrm{ml}\right)$ of serotype O111:B 4 were incubated $4 \mathrm{~h}$ at $37^{\circ} \mathrm{C}$ without HNP-4 (control; white bar) or with 0.3 to $30 \mu \mathrm{M} \mathrm{HNP}-4$ (gray bars). 
O111:B4 bacteria were killed by HNP-4. Similar levels of HNP-4 were needed for killing of E. coli ML-35 (Figure 4.3) or the serotype O111:B4 bacteria (Figure 4.4).

\section{Binding of HNP-4 to E.coli LPS}

To determine whether HNP-4 binds to purified E. coli LPS, E. coli ML-35 bacteria $\left(10^{6} \mathrm{CFU} / \mathrm{ml}\right)$ were incubated $4 \mathrm{~h}$ at $37^{\circ} \mathrm{C}$ with $10 \mu \mathrm{M} \mathrm{HNP}-4$ and various concentrations of purified E. coli LPS from 0 to $10 \mu \mathrm{M}$. Killing was determined by diluting, plating, and counting colonies. The goal was to determine whether the purified LPS would absorb the HNP-4 and block killing of the bacteria.

Figure 4.5 shows that when no HNP-4 was added, the number of bacteria increased almost 100 -fold. Incubating with $10 \mu \mathrm{M}$ LPS did not promote or inhibit growth. When $10 \mu \mathrm{M}$ HNP-4 was added, HNP-4 caused $99.2 \pm 0.4 \%$ killing. Adding LPS from 1 to $5 \mu \mathrm{M}$ along with HNP-4 caused a concentration-dependent decrease in killing. With $10 \mu \mathrm{M}$ HNP-4 and $5 \mu \mathrm{M}$ LPS, growth was the same as without HNP-4. The amount of LPS that was needed to block was an LPS to HNP-4 ratio of 1:2.

The results show that the effect of LPS on killing by HNP-4 was a result of LPS absorbing HNP-4 and not an effect of LPS on bacterial growth, because LPS had no effect when LPS was added without HNP-4.

\section{Blocking of HNP-4 Activity by LPS Fragments}

The aim of these experiments was to determine whether the oligosaccharide, core, or lipid A part of LPS is the site where HNP-4 binds. Chemically-derived LPS fragments and LPS preparations from E. coli rough mutants were tested for their ability to absorb HNP-4 and block killing of E. coli.

\section{Role of the Lipid A Part of LPS in HNP-4 Binding}

Two approaches were used to determine whether lipid A is the site where HNP-4 binds to LPS. We tested an LPS fragment that does not have a complete lipid A, and we tested pure lipid A.

\section{Effect of Deacylated LPS on Killing by HNP-4}

The aim of this experiment was to determine whether HNP-4 binds to the hydrophobic fatty acids of the lipid A part of LPS. Deacylated-LPS (deacyl-LPS) has been chemically treated to remove the fatty acids. If HNP-4 binds to the hydrophobic part of lipid A, then binding to deacyl-LPS will be weaker than binding to intact LPS. 


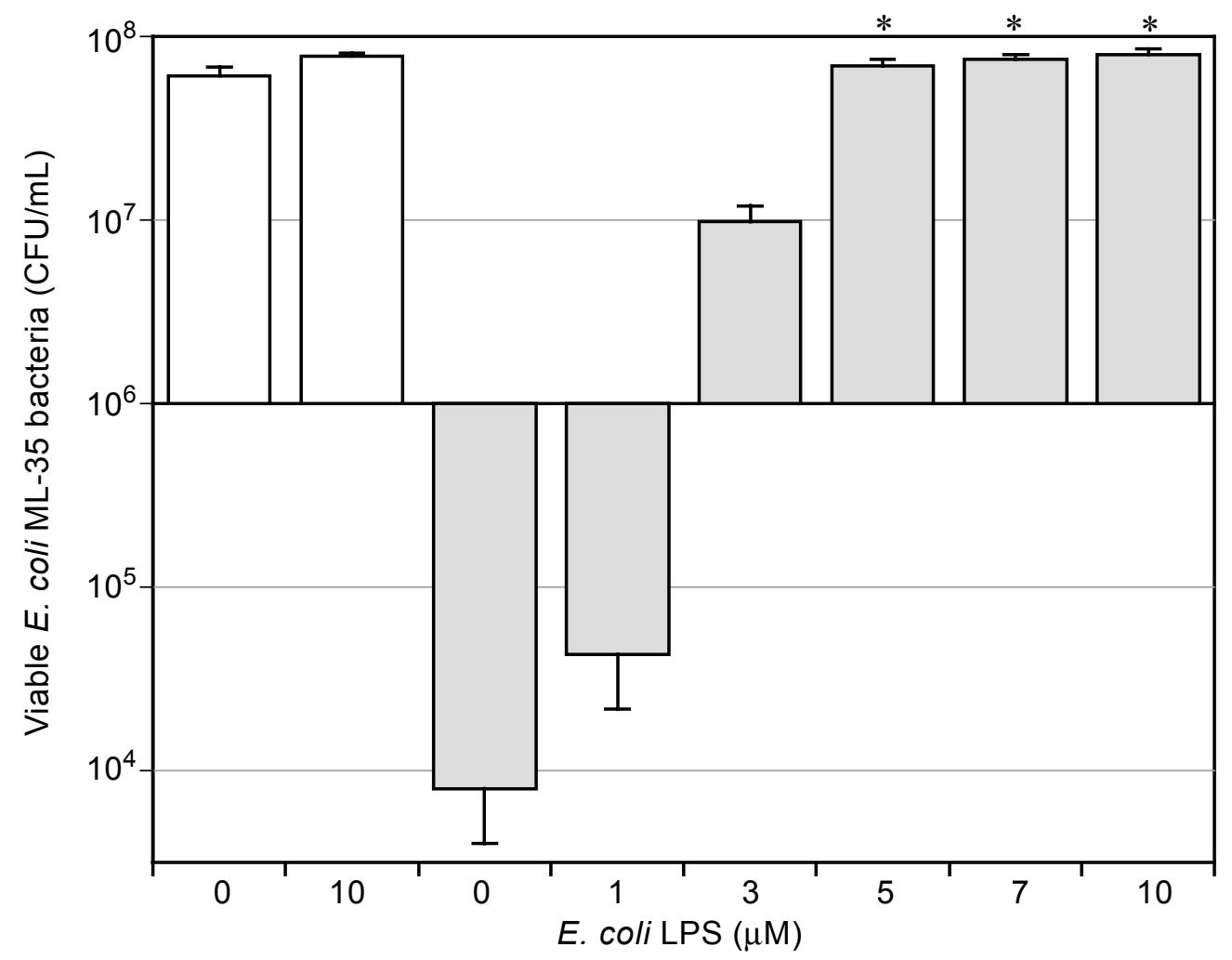

Conditions

Viable bacteria $\left(10^{6} \mathrm{CFU} / \mathrm{ml}\right)$

S.E.

P Value

\begin{tabular}{lrrrr}
\hline Control $\left(4 \mathrm{~h}, 37^{\circ} \mathrm{C}\right)$ & 61.009 & 7.374 & 4 & - \\
$10 \mu \mathrm{M}$ LPS & 78.378 & 2.703 & 2 & - \\
$10 \mu \mathrm{M}$ HNP-4 & 0.008 & 0.004 & 4 & - \\
$10 \mu \mathrm{M} \mathrm{HNP}-4+1 \mu \mathrm{M}$ LPS & 0.043 & 0.022 & 2 & 1.0 \\
$10 \mu \mathrm{M} \mathrm{HNP}-4+3 \mu \mathrm{M}$ LPS & 9.730 & 2.203 & 2 & 1.0 \\
$10 \mu \mathrm{M} \mathrm{HNP}-4+5 \mu \mathrm{M}$ LPS & 68.823 & 6.281 & 4 & $<0.0001^{*}$ \\
$10 \mu \mathrm{M}$ HNP-4 + $7 \mu \mathrm{M}$ LPS & 75.000 & 4.730 & 2 & $<0.0001^{*}$ \\
$10 \mu \mathrm{M}$ HNP-4 + $10 \mu \mathrm{M}$ LPS & 79.730 & 5.405 & 2 & $<0.0001^{*}$ \\
\hline
\end{tabular}

* Significantly different from the value with HNP-4 alone.

Figure 4.5. E. coli LPS blocks HNP-4 killing of $E$. coli ML-35.

E. coli ML-35 bacteria $\left(10^{6} / \mathrm{ml}\right)$ with 0 or $10 \mu \mathrm{M} \mathrm{E}$. coli LPS were incubated $4 \mathrm{~h}$ at $37^{\circ} \mathrm{C}$, diluted, and plated (white bars). Alternatively, the bacteria were incubated with $10 \mu \mathrm{M}$ HNP-4 and 0 to $10 \mu \mathrm{M}$ purified LPS from E. coli of serotype O111:B4 (gray bars). 
E. coli ML-35 bacteria were incubated with $10 \mu \mathrm{M}$ HNP-4 and various concentrations of deacyl-LPS. Figure 4.6 shows that $10 \mu \mathrm{M}$ deacyl-LPS alone did not promote or inhibit growth. HNP-4 $(10 \mu \mathrm{M})$ killed $96 \pm 3 \%$ of the E. coli. Deacyl-LPS was nearly as effective as intact LPS at blocking HNP-4. Deacyl-LPS at 5-7 $\mu \mathrm{M}$ or intact LPS at 3-5 $\mu \mathrm{M}$ (Figure 4.5) was needed to block $10 \mu \mathrm{M}$ HNP-4. Therefore, the fatty acids of LPS were not required for binding of HNP-4 to LPS. This result indicates that HNP-4 must bind to some other part of LPS, such as the oligosaccharide, core, or the part of lipid A that remains when the fatty acids are removed from LPS.

\section{Effect of Lipid A on Killing by HNP-4}

Lipid A contains fatty acids, glucosamine, and phosphate groups. Phosphate groups are negatively charged, and HNP-4 has a net positive charge, so phosphate groups of lipid A might be the site where HNP-4 binds to LPS. To test the effect of lipid A, E. coli ML-35 bacteria were incubated with $10 \mu \mathrm{M}$ HNP-4 and various concentrations of lipid A, which was solubilized with triethylamine. In control experiments (not shown), these low concentrations of triethylamine had no effect on growth.

Figure 4.7 shows that $20 \mu \mathrm{M}$ lipid A alone had no effect on growth of the bacteria. Lipid A did not block HNP-4 killing even at 2:1 ratio of lipid A to HNP-4, whereas a 1:2 ratio of LPS to HNP-4 was enough to block killing. Therefore, HNP-4 does not bind to the lipid A part of LPS.

\section{Role of the LPS Core in HNP-4 Binding}

The highly variable oligosaccharide part of LPS is linked to the less-variable LPS core. The core can be divided into inner and outer core. The goal of these experiments was to determine if HNP-4 binds to the LPS core and if so, whether it binds to the inner or outer core.

Figure 4.8 shows structures of the LPS fragments used in these experiments. These fragments are from E. coli K12 mutants with defects in LPS synthesis $(33,38)$. Kdo2-lipid A has only 2 of the 3 Kdo units of the LPS core (59). Re LPS has 3 Kdo units and a phosphoryl-ethanolamine group, which is attached to a Kdo unit. Rc LPS has the complete inner core with $3 \mathrm{Kdo}$ units, 3 heptose units, pyrophosphorylethanolamine, phosphoryl-ethanolamine, and a phosphate group. It also has two hexose units, galactose and glucose, which are part of the outer core. Ra LPS has the complete inner core and the outer core, which is a branched polysaccharide containing hexoses and one heptose unit. 


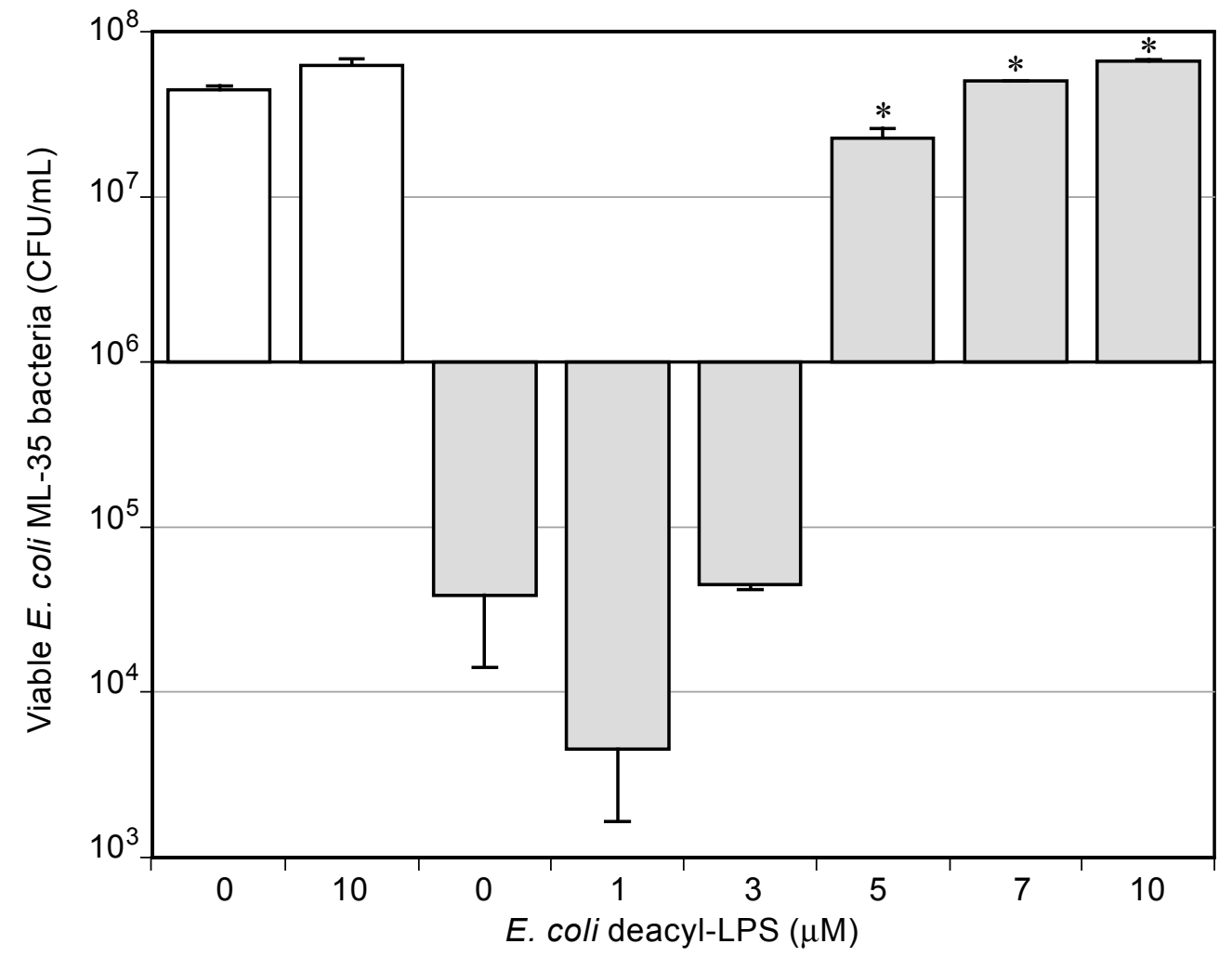

Conditions

Viable bacteria $\left(10^{6} \mathrm{CFU} / \mathrm{ml}\right)$

S.E. $\quad \mathrm{n} \quad$ P Value

\begin{tabular}{lcccc}
\hline Control $\left(4 \mathrm{~h}, 37^{\circ} \mathrm{C}\right)$ & 44.388 & 2.490 & 4 & - \\
$10 \mu \mathrm{M}$ deacyl-LPS & 62.181 & 2.359 & 4 & - \\
$10 \mu \mathrm{M}$ HNP-4 & 0.038 & 0.030 & 4 & - \\
$10 \mu \mathrm{M}$ HNP-4 + $1 \mu \mathrm{M}$ deacyl-LPS & 0.004 & 0.024 & 2 & 1.0 \\
$10 \mu \mathrm{M}$ HNP-4 + $3 \mu \mathrm{M}$ deacyl-LPS & 0.045 & 0.001 & 2 & 1.0 \\
$10 \mu \mathrm{M}$ HNP-4 + $5 \mu \mathrm{M}$ deacyl-LPS & 22.707 & 3.284 & 3 & $0.0002^{*}$ \\
$10 \mu \mathrm{M}$ HNP-4 $+7 \mu \mathrm{M}$ deacyl-LPS & 50.286 & 0.000 & 2 & $<0.0001^{*}$ \\
$10 \mu \mathrm{M}$ HNP-4 + $10 \mu \mathrm{M}$ deacyl-LPS & 65.986 & 2.007 & 3 & $<0.0001^{*}$ \\
\hline
\end{tabular}

* Significantly different from the value with HNP-4 alone.

Figure 4.6. Deacyl-LPS blocks HNP-4 killing of $E$. coli ML-35.

E. coli ML-35 bacteria $\left(10^{6} / \mathrm{ml}\right)$ with 0 or $10 \mu \mathrm{M}$ deacyl-LPS were incubated $4 \mathrm{~h}$ at $37^{\circ} \mathrm{C}$ and then diluted and plated (white bars). Alternatively, the bacteria were incubated with $10 \mu \mathrm{M}$ HNP-4 and various levels of deacyl-LPS (gray bars). 


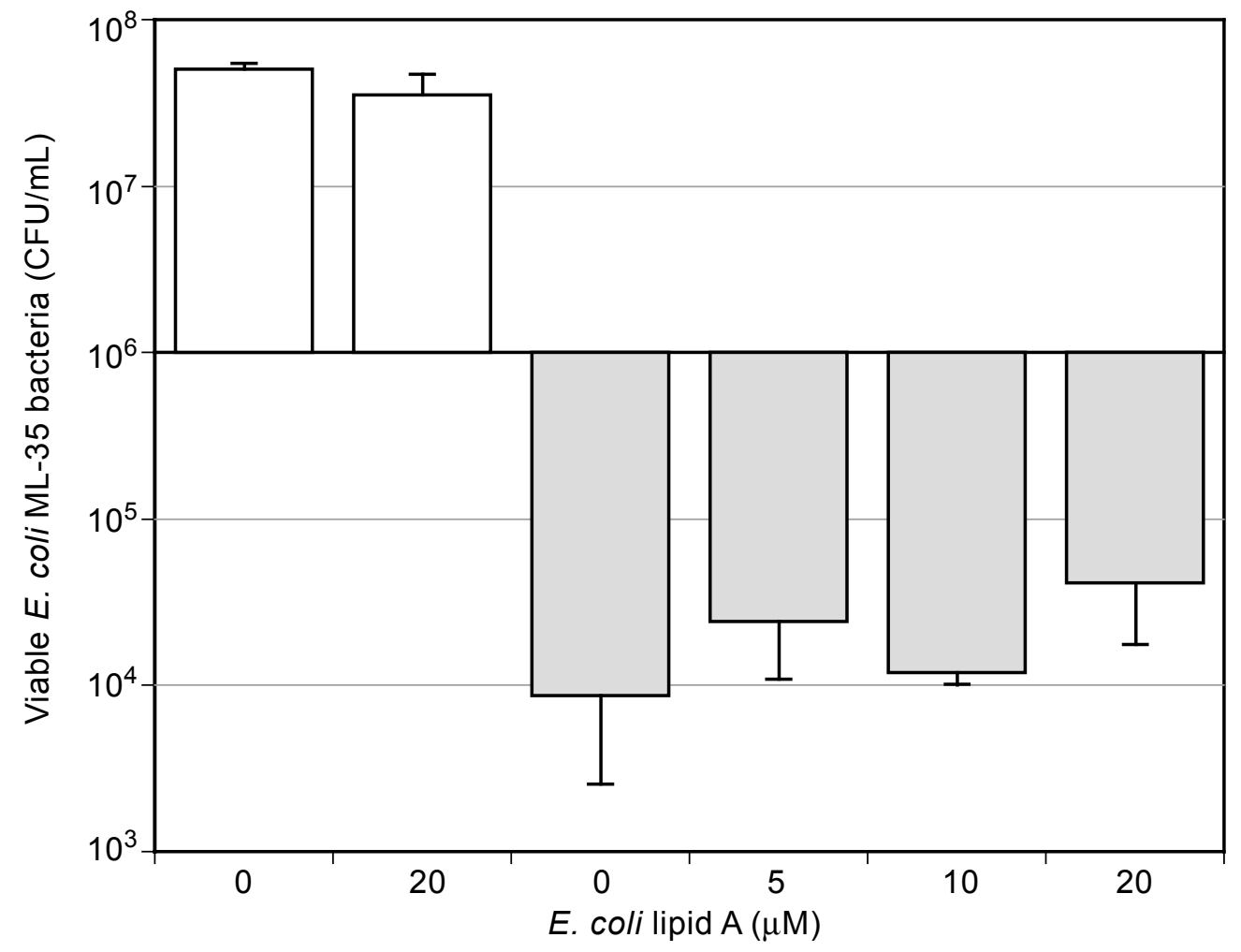

Conditions

Viable bacteria $\left(10^{6} \mathrm{CFU} / \mathrm{ml}\right)$

S.E.

P Value

\begin{tabular}{lrrrr}
\hline Control $\left(4 \mathrm{~h}, 37^{\circ} \mathrm{C}\right)$ & 50.437 & 4.304 & 4 & - \\
$20 \mu \mathrm{M}$ Lipid A & 35.294 & 11.765 & 2 & - \\
$10 \mu \mathrm{M}$ HNP-4 & 0.009 & 0.006 & 4 & - \\
$10 \mu \mathrm{M}$ HNP-4 + $5 \mu \mathrm{M}$ lipid A & 0.024 & 0.013 & 3 & 1.0 \\
$10 \mu \mathrm{M}$ HNP-4 + $10 \mu \mathrm{M}$ lipid A & 0.012 & 0.002 & 3 & 1.0 \\
$10 \mu \mathrm{M}$ HNP-4 + $20 \mu \mathrm{M}$ lipid A & 0.041 & 0.024 & 2 & 1.0 \\
\hline
\end{tabular}

Figure 4.7. Lipid A does not block HNP-4 killing of $E$. coli ML-35.

E. coli ML-35 bacteria $\left(10^{6} / \mathrm{ml}\right)$ with 0 or $20 \mu \mathrm{M} \mathrm{E}$. coli lipid A were incubated $4 \mathrm{~h}$ at $37^{\circ} \mathrm{C}$ and then diluted and plated (white bars). Alternatively, the bacteria were incubated with $10 \mu \mathrm{M} \mathrm{HNP}-4$ and various levels of purified E. coli lipid A (gray bars). 
Kdo2-lipid $A$

Kdo - Lipid A
Kdo

$\operatorname{Re} L P S$

Kdo - Lipid A

I

Kdo - PEtn

Kdo

Rc LPS

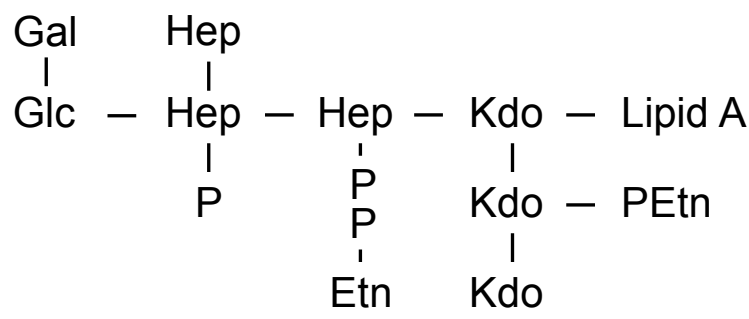

Ra LPS

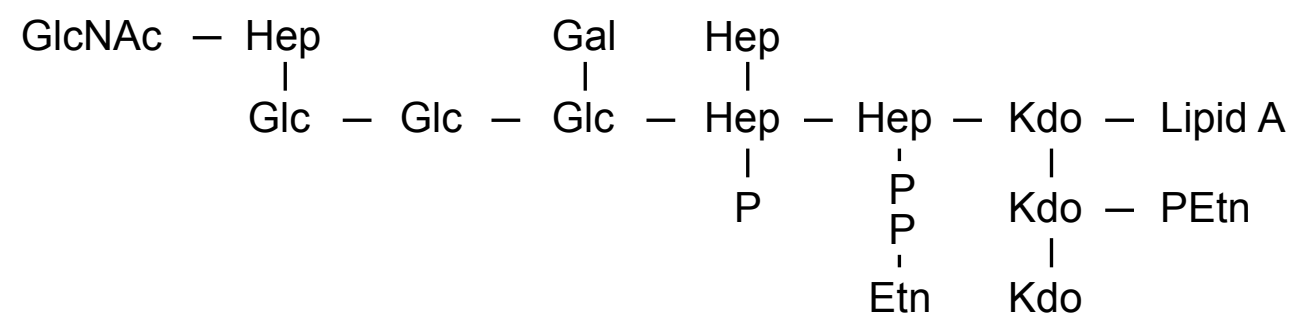

Figure 4.8. Structures of Kdo2-lipid A and LPS from rough mutants.

$\mathrm{Kdo}_{2}$-lipid $\mathrm{A}$ is an LPS fragment isolated from a rough mutant of $E$. coli. LPS from the Re mutant has the three Kdo units of the inner core, but not the three heptose units. The Rc mutant has the complete inner core plus a glucose (Glc) and galactose (Gal) of the outer core. The Ra mutant has the complete inner and outer core. 


\section{Effect of Kdo2-lipid A on Killing by HNP-4}

Lipid A is linked to the three Kdo sugar units of the LPS inner core. The goal of this experiment was to determine whether HNP-4 binds to Kdo groups attached to lipid A. E. coli ML-35 bacteria were incubated with $10 \mu \mathrm{M}$ HNP-4 and various concentrations of Kdo2-lipid A.

Figure 4.9 shows that Kdo2-lipid A alone had no effect on growth. Kdo2-lipid A partially blocked HNP-4 killing, but a high ratio of Kdon-lipid A to HNP-4 was needed (two Kdo2-lipid A to one HNP-4). These results indicate that HNP-4 binds to the two Kdo units of Kdo2-lipid A, but binding is not as strong as HNP-4 binding to LPS.

\section{Effects of Re, Rc, and Ra LPS on Killing by HNP-4}

The aim of these experiments was to determine whether HNP-4 binds to LPS from mutants that have partial or complete LPS cores attached to lipid A.

To test the effect of Re LPS on killing by HNP-4, E. coli ML-35 bacteria were incubated with $10 \mu \mathrm{M}$ HNP-4 and various concentrations of Re LPS from $E$. coli K12-D31m4. Figure 4.10 shows that Re LPS alone had no effect on growth of the bacteria. Re LPS completely blocked killing by HNP-4 at a ratio of about one Re LPS to one HNP-4. This results shows that Re LPS was more effective than Kdo2-

lipid A and suggests that HNP-4 binds to the Kdo units or to the Kdo and phosphorylethanolamine units of the inner core.

To test the effect of Rc LPS on killing by HNP-4, E. coli ML-35 bacteria were incubated with $10 \mu \mathrm{M}$ HNP-4 and various concentrations of Rc LPS from E. coli J5. Figure 4.11 shows that $10 \mu \mathrm{M}$ Rc LPS alone had no effect on growth of the bacteria. Rc LPS was able to completely block killing at a ratio of about one Rc LPS to two HNP-4. Therefore, Rc LPS was more effective than Re LPS, indicating that HNP-4 binding to the complete inner core of LPS with heptoses and an additional phosphate and diphosphoryl-ethanolamine moiety was stronger than binding to the Kdo units and one phosphoryl-ethanolamine.

To test the effect of Ra LPS on killing by HNP-4, E. coli ML-35 bacteria were incubated with $10 \mu \mathrm{M}$ HNP-4 and various concentrations of Ra LPS from $E$. coli EH100. Figure 4.12 shows that Ra LPS alone had no effect on growth of the bacteria. Ra LPS was able to block killing completely at a ratio of about one Ra LPS to two HNP-4. Therefore, Ra LPS was equal to Rc LPS, indicating that adding the hexose groups of the outer core did not promote HNP-4 binding. In fact, Rc LPS was as effective as intact LPS. 


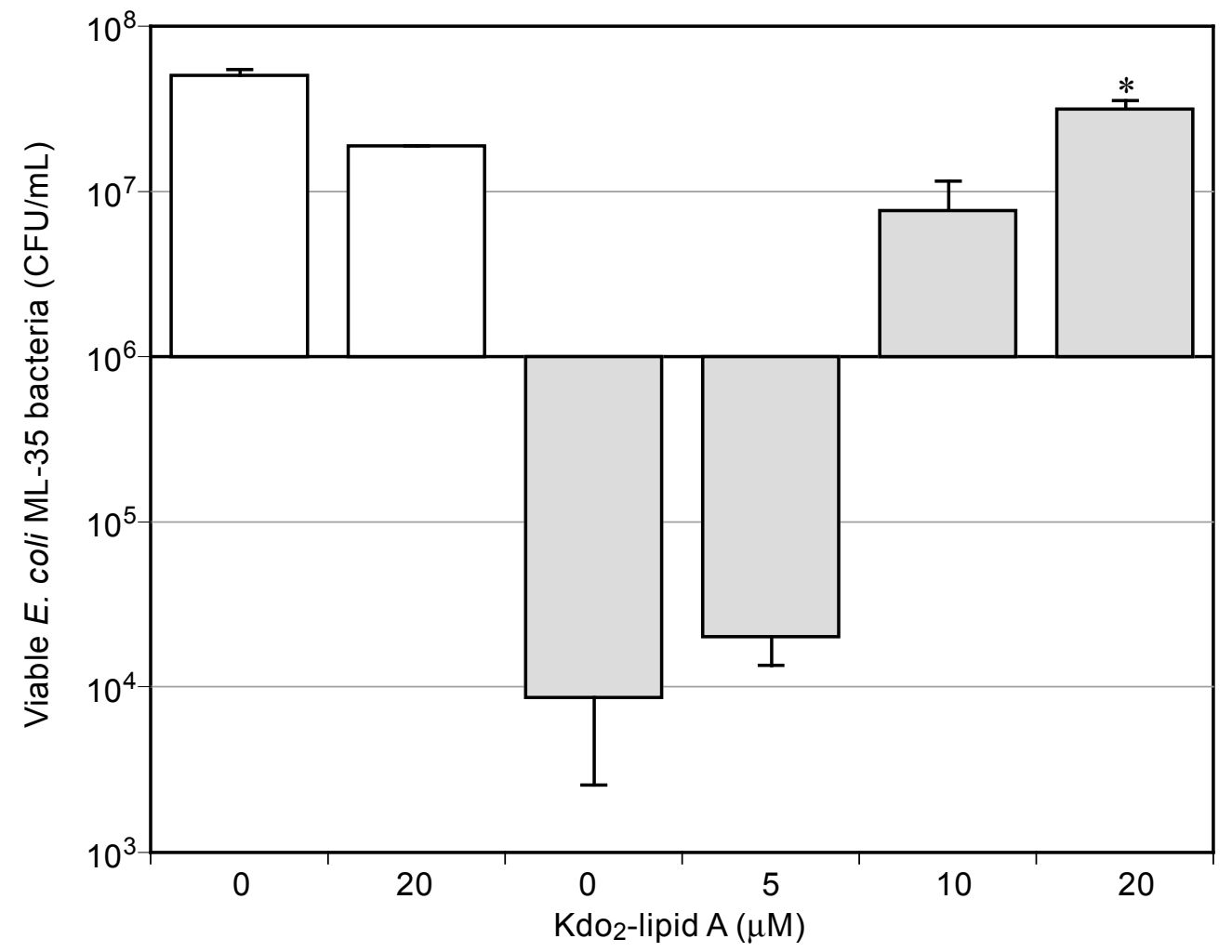

Conditions

Viable bacteria $\left(10^{6} \mathrm{CFU} / \mathrm{ml}\right)$

S.E. $n \quad$ P Value

\begin{tabular}{lrrrr} 
Control $\left(4 \mathrm{~h}, 37^{\circ} \mathrm{C}\right)$ & 50.437 & 4.304 & 4 & - \\
$20 \mu \mathrm{M} \mathrm{Kdo} 2-$ lipid A & 18.824 & 0.000 & 2 & - \\
$10 \mu \mathrm{M} \mathrm{HNP}-4$ & 0.009 & 0.006 & 4 & - \\
$10 \mu \mathrm{M}$ HNP-4 + $5 \mu \mathrm{M}$ Kdo2-lipid A & 0.020 & 0.007 & 3 & 1.0 \\
$10 \mu \mathrm{M}$ HNP-4 + $10 \mu \mathrm{M} \mathrm{Kdo}$-lipid A & 7.666 & 3.844 & 3 & 0.8 \\
$10 \mu \mathrm{M} \mathrm{HNP}-4+20 \mu \mathrm{M} \mathrm{Kdo} 2-l i p i d \mathrm{~A}$ & 31.765 & 3.529 & 2 & $0.002^{*}$ \\
\hline
\end{tabular}

* Significantly different from the value with HNP-4 alone.

Figure 4.9. Kdo-lipid A blocks HNP-4 killing of E. coli ML-35.

E. coli ML-35 bacteria $\left(10^{6} / \mathrm{ml}\right)$ with 0 or $20 \mu \mathrm{M} \mathrm{Kdo} 2$-lipid A were incubated $4 \mathrm{~h}$ at $37^{\circ} \mathrm{C}$ and then diluted and plated (white bars). Alternatively, the bacteria were incubated with $10 \mu \mathrm{M} \mathrm{HNP}-4$ and various levels of purified Kdoz-lipid A (gray bars). 


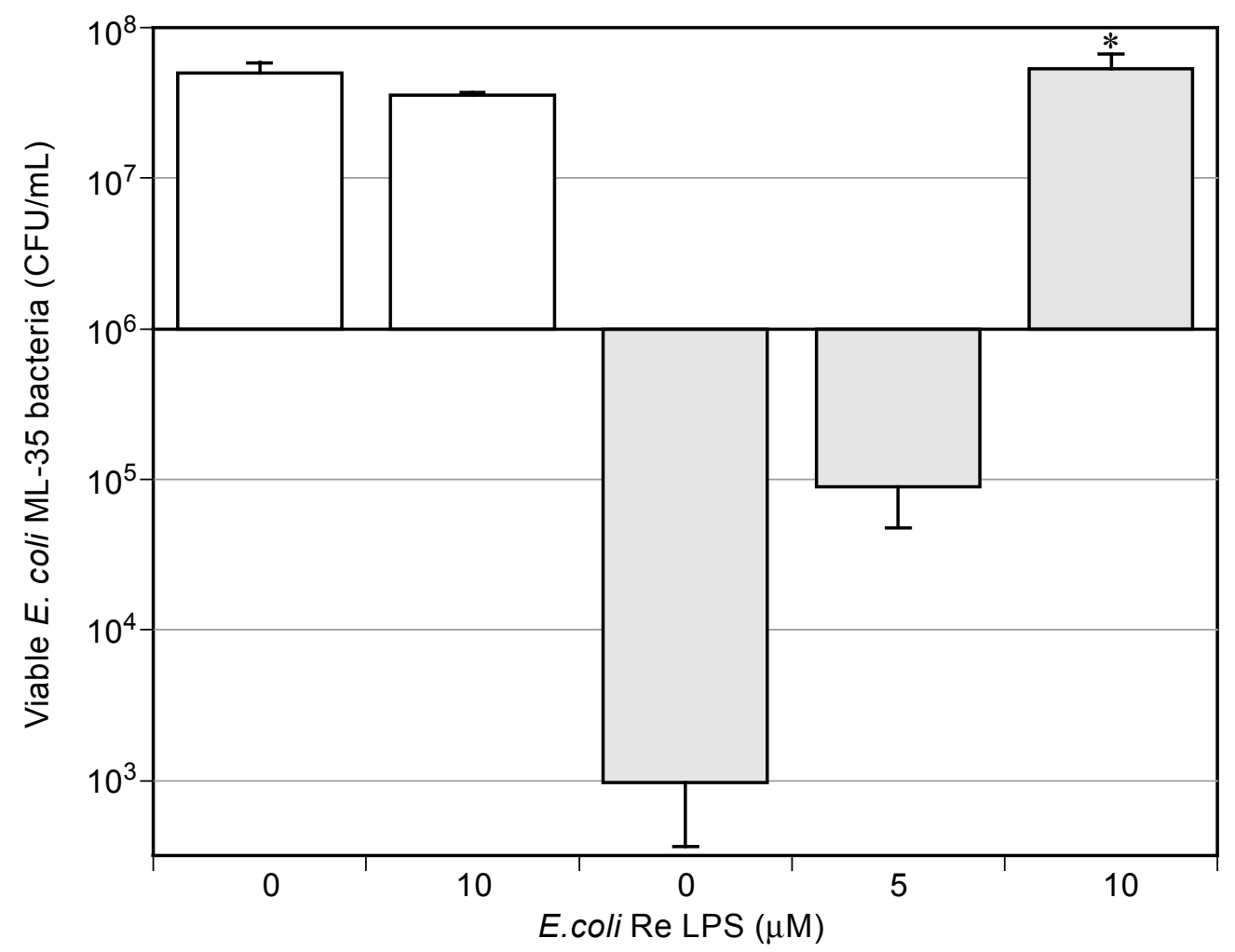

Conditions

Viable bacteria $\left(10^{6} \mathrm{CFU} / \mathrm{ml}\right)$

S.E. $\quad n \quad$ P Value

\begin{tabular}{lrrrr}
\hline Control $\left(4 \mathrm{~h}, 37^{\circ} \mathrm{C}\right)$ & 50.532 & 7.979 & 2 & - \\
$10 \mu \mathrm{M}$ Re LPS & 35.638 & 1.596 & 2 & - \\
$10 \mu \mathrm{M} \mathrm{HNP}-4$ & 0.001 & 0.001 & 2 & - \\
$10 \mu \mathrm{M} \mathrm{HNP}-4+5 \mu \mathrm{M}$ Re LPS & 0.090 & 0.042 & 2 & 1.0 \\
$10 \mu \mathrm{M} \mathrm{HNP}-4+10 \mu \mathrm{M}$ Re LPS & 53.723 & 13.298 & 2 & $0.02 *$ \\
\hline
\end{tabular}

* Significantly different from the value with HNP-4 alone.

Figure 4.10. Rough (Re) LPS blocks HNP-4 killing of E. coli ML-35.

E. coli ML-35 bacteria $\left(10^{6} / \mathrm{ml}\right)$ with 0 or $10 \mu \mathrm{M}$ rough (Re) E. coli LPS were incubated $4 \mathrm{~h}$ at $37^{\circ} \mathrm{C}$ and then diluted and plated (white bars). Alternatively, the bacteria were incubated with $10 \mu \mathrm{M} \mathrm{HNP}-4$ and various levels of rough (Re) LPS from E. coli $\mathrm{K} 12-\mathrm{D} 31 \mathrm{~m} 4$ (gray bars). 


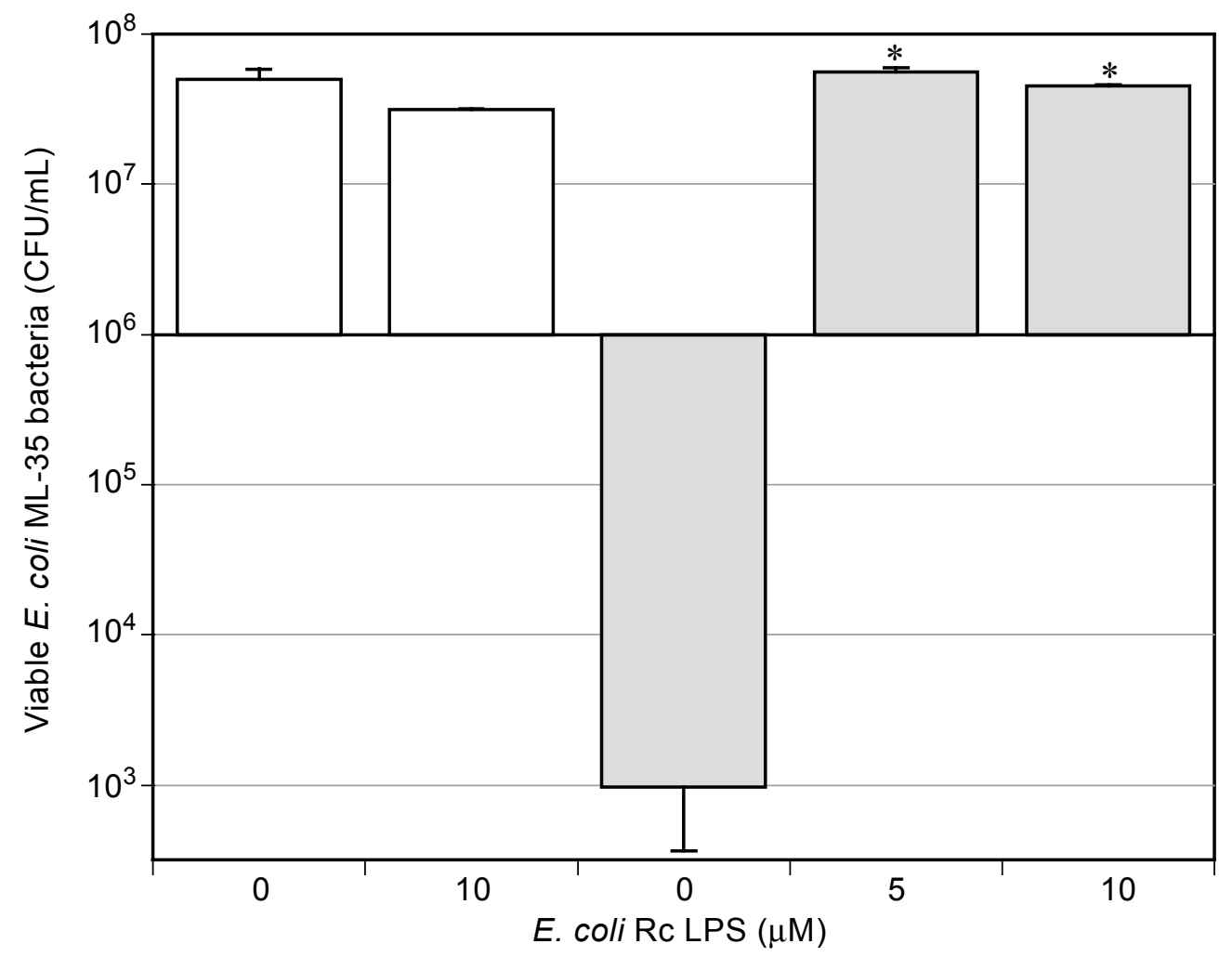

Conditions

Viable bacteria $\left(10^{6} \mathrm{CFU} / \mathrm{ml}\right)$

S.E.

n P Value

\begin{tabular}{lrrrr}
\hline Control $\left(4 \mathrm{~h}, 37^{\circ} \mathrm{C}\right)$ & 50.532 & 7.979 & 2 & - \\
$10 \mu \mathrm{M} \mathrm{Rc}$ LPS & 31.383 & 0.532 & 2 & - \\
$10 \mu \mathrm{M} \mathrm{HNP}-4$ & 0.001 & 0.001 & 2 & - \\
$10 \mu \mathrm{M} \mathrm{HNP}-4+5 \mu \mathrm{M}$ Rc LPS & 55.851 & 3.723 & 2 & $0.002^{*}$ \\
$10 \mu \mathrm{M} \mathrm{HNP}-4+10 \mu \mathrm{M}$ Rc LPS & 45.213 & 0.532 & 2 & $0.005^{*}$
\end{tabular}

* Significantly different from the value with HNP-4 alone.

Figure 4.11. Rough (Rc) LPS blocks HNP-4 killing of E. coli ML-35. E. coli ML-35 bacteria $\left(10^{6} / \mathrm{ml}\right)$ with 0 or $10 \mu \mathrm{M}$ rough (Rc) E. coli LPS were incubated $4 \mathrm{~h}$ at $37^{\circ} \mathrm{C}$ and then diluted and plated (white bars). Alternatively, the bacteria were incubated with $10 \mu \mathrm{M} \mathrm{HNP}-4$ and various levels of purified rough (Rc) LPS from E. coli J5 (gray bars). 


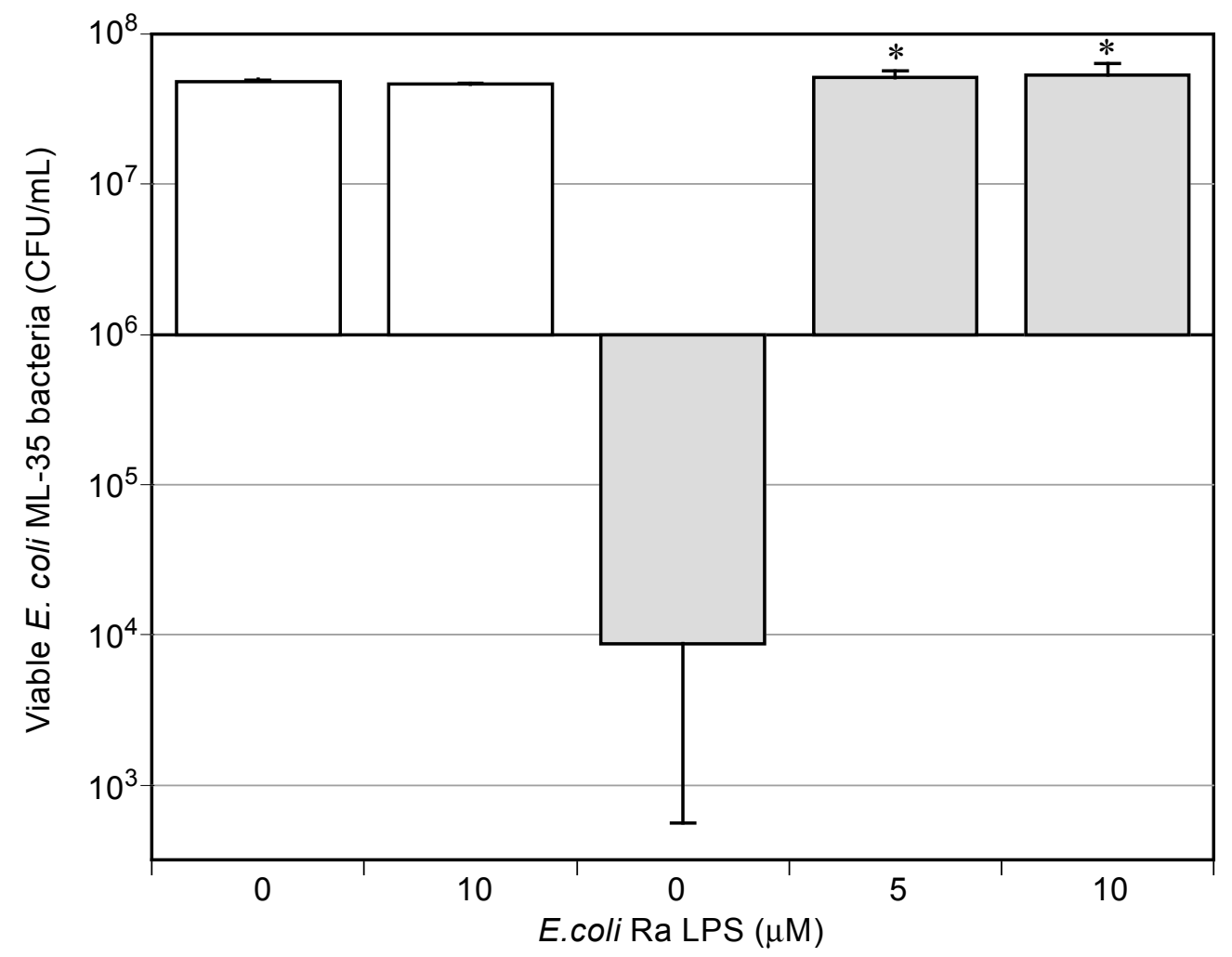

Conditions

Viable bacteria $\left(10^{6} \mathrm{CFU} / \mathrm{ml}\right)$

S.E.

n P Value

\begin{tabular}{lrrrr}
\hline Control $\left(4 \mathrm{~h}, 37^{\circ} \mathrm{C}\right)$ & 48.370 & 1.630 & 2 & - \\
$10 \mu \mathrm{M}$ Ra LPS & 46.196 & 0.544 & 2 & - \\
$10 \mu \mathrm{M}$ HNP-4 & 0.009 & 0.008 & 2 & - \\
$10 \mu \mathrm{M}$ HNP-4 + $5 \mu \mathrm{M}$ Ra LPS & 51.630 & 4.891 & 2 & $0.01^{*}$ \\
$10 \mu \mathrm{M}$ HNP-4 + $10 \mu \mathrm{M}$ Ra LPS & 53.261 & 9.783 & 2 & $0.01^{*}$ \\
\hline
\end{tabular}

* Significantly different from the value with HNP-4 alone.

Figure 4.12. Rough (Ra) LPS blocks HNP-4 killing of $E$. coli ML-35.

E. coli ML-35 bacteria $\left(10^{6} / \mathrm{ml}\right)$ with 0 or $10 \mu \mathrm{M}$ rough (Ra) E. coli LPS were incubated $4 \mathrm{~h}$ at $37^{\circ} \mathrm{C}$ and then diluted and plated (white bars). Alternatively, the bacteria were incubated with $10 \mu \mathrm{M} \mathrm{HNP}-4$ and various levels of purified rough (Ra) LPS from E. coli EH100 (gray bars). 


\section{Killing of E. coli J5 by HNP-4}

If HNP-4 binds to the inner core of LPS, then HNP-4 should kill the Rc mutant E. coli J5. Rc mutants lack the oligosaccharide part of LPS and most of the outer core and might be more sensitive than E. coli ML-35 to killing by HNP-4. The aim of this experiment was to determine whether HNP-4 has strong activity against an Rc mutant. Bacteria $\left(10^{6} \mathrm{CFU} / \mathrm{mL}\right)$ were incubated $4 \mathrm{~h}$ at $37^{\circ}$ with various concentrations of HNP-4. Figure 4.13 shows that $5 \mu \mathrm{M} \mathrm{HNP}-4$ killed $99 \%$ of the bacteria. In results shown earlier (Figure 4.3), $10 \mu \mathrm{M} \mathrm{HNP}-4$ was needed to kill 99\% of the E. coli ML-35 bacteria. Therefore, E. coli J5, an Rc mutant that lacks oligosaccharide and most of the outer core, is killed by HNP-4 and is about twice as sensitive as E. coli ML-35 to killing by HNP-4.

In other experiments (not shown), E. coli J5 was found to be less sensitive to killing by HNP-1 than $E$. coli ML-35. HNP-1 at $5 \mu \mathrm{M}$ killed $99 \%$ of $E$. coli ML-35, but $10 \mu \mathrm{M}$ HNP-1 was needed for $99 \%$ killing of $E$. coli J5.

\section{Activity of HNP-4 against $A$.a.}

Periodontal pathogens such as A.a. are resistant to killing by HNP-1, -2 or -3 (26). The goal of these experiments was to determine whether A.a. is also resistant to HNP-4, or whether HNP-4 is more effective than other alpha-defensins against this gram-negative organism.

To determine whether A.a. is resistant to HNP-4, A.a. Y4 bacteria $\left(10^{6} \mathrm{CFU} / \mathrm{ml}\right)$ in dilute growth medium (1\% TSB) with $10 \mathrm{mM}$ phosphate $\mathrm{pH} 7.4$ buffer were diluted and plated immediately, or incubated $4 \mathrm{~h}$ at $37^{\circ} \mathrm{C}$ with 0 to $30 \mu \mathrm{M} \mathrm{HNP}-4$ or $3 \mu \mathrm{M}$ polymyxin $\mathrm{B}$. Incubations were carried out in 96 well plates in an atmosphere with low $\mathrm{O}_{2}$ and elevated $(5-10 \%) \mathrm{CO}_{2}$ generated inside a BBL ${ }^{\mathrm{TM}}$ GasPak Pouch ${ }^{\mathrm{TM}}$ Anaerobic System. At the end of the incubation, the number of viable bacteria was determined by diluting, plating, and counting colonies.

Figure 4.14 shows that A.a. grew slowly, resulting in about a 10 -fold increase in the number of viable bacteria rather than the 100-fold increase seen in experiments with E. coli. HNP-4 at concentrations up to $30 \mu \mathrm{M}$ did not kill A.a. Y4. There was partial inhibition of growth, but inhibition did not increase with increasing concentrations of HNP-4. In contrast, the gram-negative specific antibiotic polymyxin B at $3 \mu \mathrm{M}$ killed $>99.9 \%$ of the $A$.a. bacteria (not shown), confirming that the bacteria could be killed under these experimental conditions. The results indicate that A.a. Y4 is highly resistant to HNP-4. 


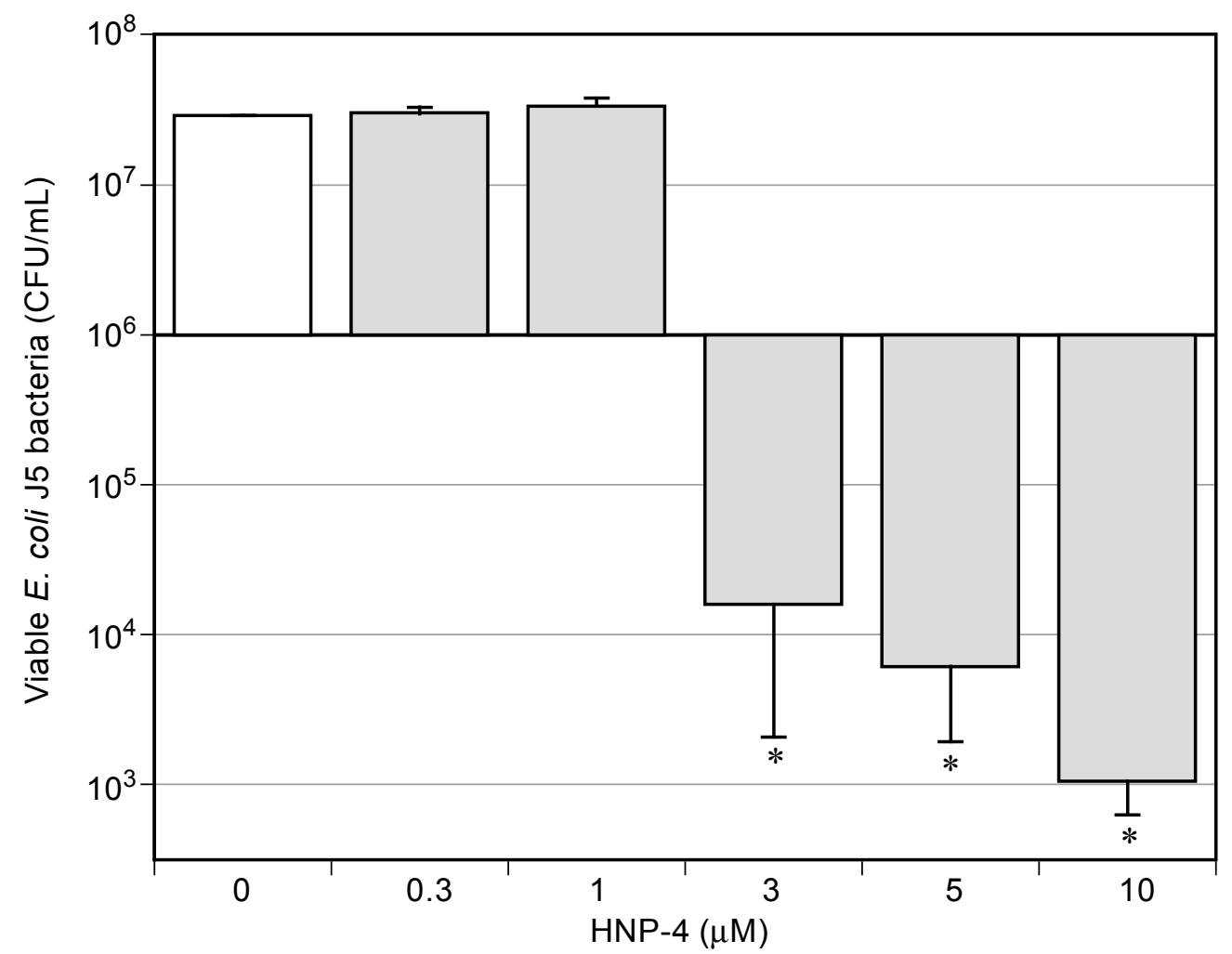

\begin{tabular}{lcccr}
\hline Conditions & $\begin{array}{c}\text { Viable bacteria } \\
\left(10^{6} \mathrm{CFU} / \mathrm{ml}\right)\end{array}$ & S.E. & $\mathrm{n}$ & P Value \\
\hline Control $\left(4 \mathrm{~h}, 37^{\circ} \mathrm{C}\right)$ & 28.713 & 0.000 & 2 & - \\
HNP-4, $0.3 \mu \mathrm{M}$ & 29.703 & 2.971 & 2 & 1.0 \\
$\mathrm{HNP}-4,1 \mu \mathrm{M}$ & 33.168 & 4.455 & 2 & 0.8 \\
$\mathrm{HNP}-4,3 \mu \mathrm{M}$ & 0.016 & 0.014 & 2 & $0.002^{*}$ \\
$\mathrm{HNP}-4,5 \mu \mathrm{M}$ & 0.006 & 0.004 & 2 & $0.002 *$ \\
$\mathrm{HNP}-4,10 \mu \mathrm{M}$ & 0.001 & 0.000 & 2 & $0.002 *$ \\
\hline
\end{tabular}

* Significantly different from the control value without HNP-4.

Figure 4.13. HNP-4 kills rough $(\mathrm{Rc})$ E. coli $\mathrm{J5}$.

E. coli $\mathrm{J} 5$ bacteria $\left(10^{6} / \mathrm{ml}\right)$ were incubated $4 \mathrm{~h}$ at $37^{\circ} \mathrm{C}$ without HNP-4 (control; white bar) or with 0.3 to $10 \mu \mathrm{M} \mathrm{HNP}-4$ (gray bars). 


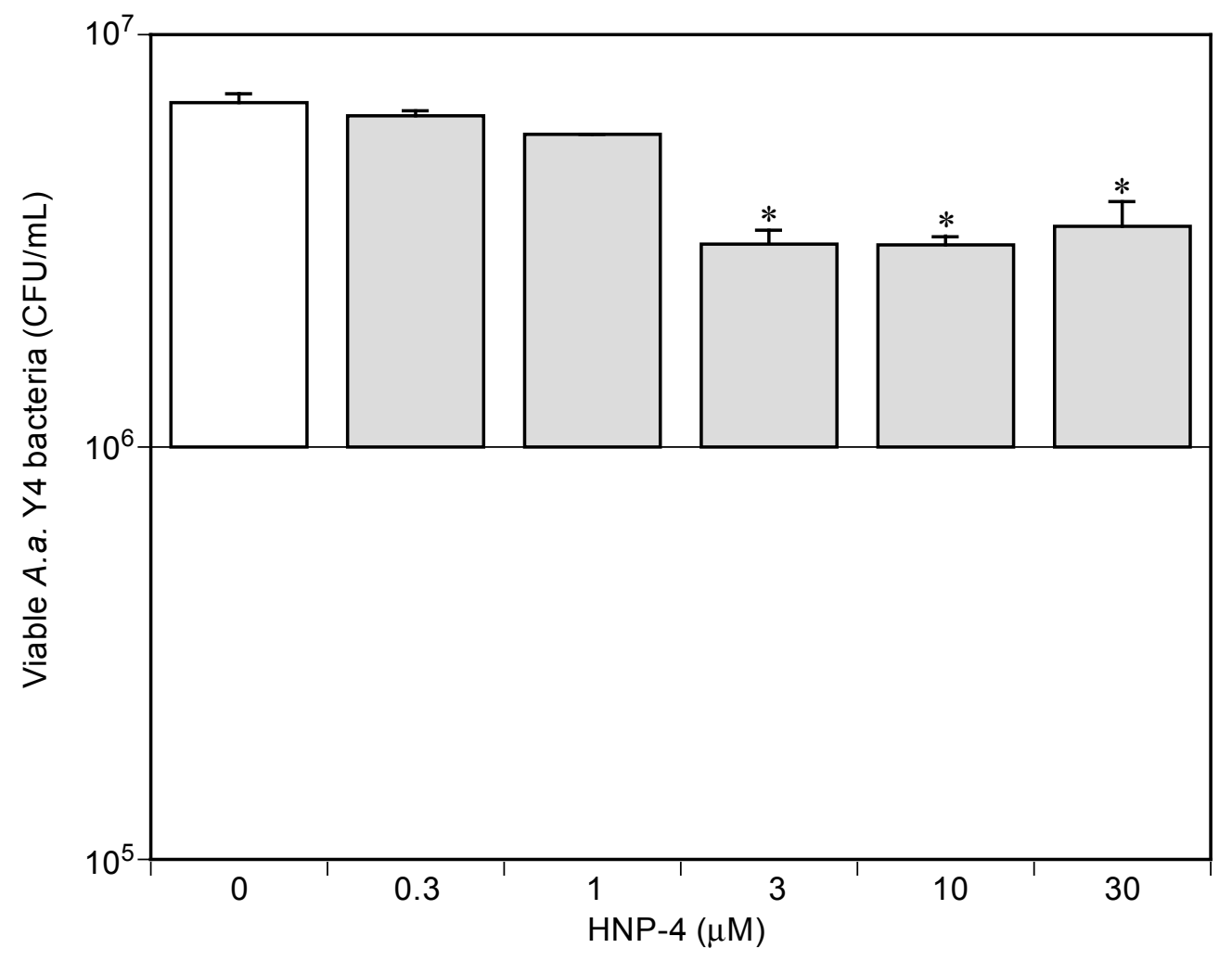

\begin{tabular}{lcccr} 
Conditions & $\begin{array}{c}\text { Viable bacteria } \\
\left(10^{6} \mathrm{CFU} / \mathrm{ml}\right)\end{array}$ & S.E. & $\mathrm{n}$ & P Value \\
\hline Control $\left(4 \mathrm{~h}, 37^{\circ} \mathrm{C}\right)$ & 6.865 & 0.324 & 2 & - \\
$\mathrm{HNP}-4,0.3 \mu \mathrm{M}$ & 6.351 & 0.189 & 2 & 0.9 \\
$\mathrm{HNP}-4,1 \mu \mathrm{M}$ & 5.730 & 0.000 & 2 & 0.3 \\
$\mathrm{HNP}-4,3 \mu \mathrm{M}$ & 3.108 & 0.243 & 2 & $0.002 *$ \\
$\mathrm{HNP}-4,10 \mu \mathrm{M}$ & 3.081 & 0.162 & 2 & $0.002 *$ \\
$\mathrm{HNP}-4,30 \mu \mathrm{M}$ & 3.432 & 0.514 & 2 & $0.003 *$
\end{tabular}

* Significantly different from the control value without HNP-4.

Figure 4.14. HNP-4 inhibits $A$.a. growth.

A.a. Y4 bacteria $\left(10^{6} / \mathrm{ml}\right)$ were incubated $4 \mathrm{~h}$ at $37^{\circ} \mathrm{C}$ without $\mathrm{HNP}-4$ (control; white bar) or with 0.3 to $30 \mu \mathrm{M} \mathrm{HNP}-4$ (gray bars). 


\section{Binding of HNP-4 to A.a. LPS}

The aim of these experiments was to determine whether HNP-4 is unable to kill A. a. because LPS on the surface of A.a. can't act as a receptor for HNP-4. E. coli ML-35 ( $\left.10^{6} \mathrm{CFU} / \mathrm{mL}\right), 10 \mu \mathrm{M}$ HNP-4, and various concentrations of LPS purified from the Y4 strain of $A . a$. were diluted and plated immediately or incubated $4 \mathrm{~h}$ at $37^{\circ} \mathrm{C}$.

If HNP-4 can't bind to A.a. LPS, then A.a. LPS should not absorb HNP-4 and block killing of $E$. coli. Figure 4.15 shows that in the absence of HNP-4 the $E$. coli grew and increased in number nearly 100 -fold. Adding purified A.a. LPS did not promote or inhibit the growth of E. coli. HNP-4 at $10 \mu \mathrm{M}$ killed $94 \pm 3 \%$ of the E. coli. Purified A.a. LPS ( 3 to $5 \mu \mathrm{M}$ ) blocked the action of $10 \mu \mathrm{M} \mathrm{HNP}-4$.

Therefore, A. a. LPS was as effective as E. coli LPS in binding HNP-4 and blocking killing. 


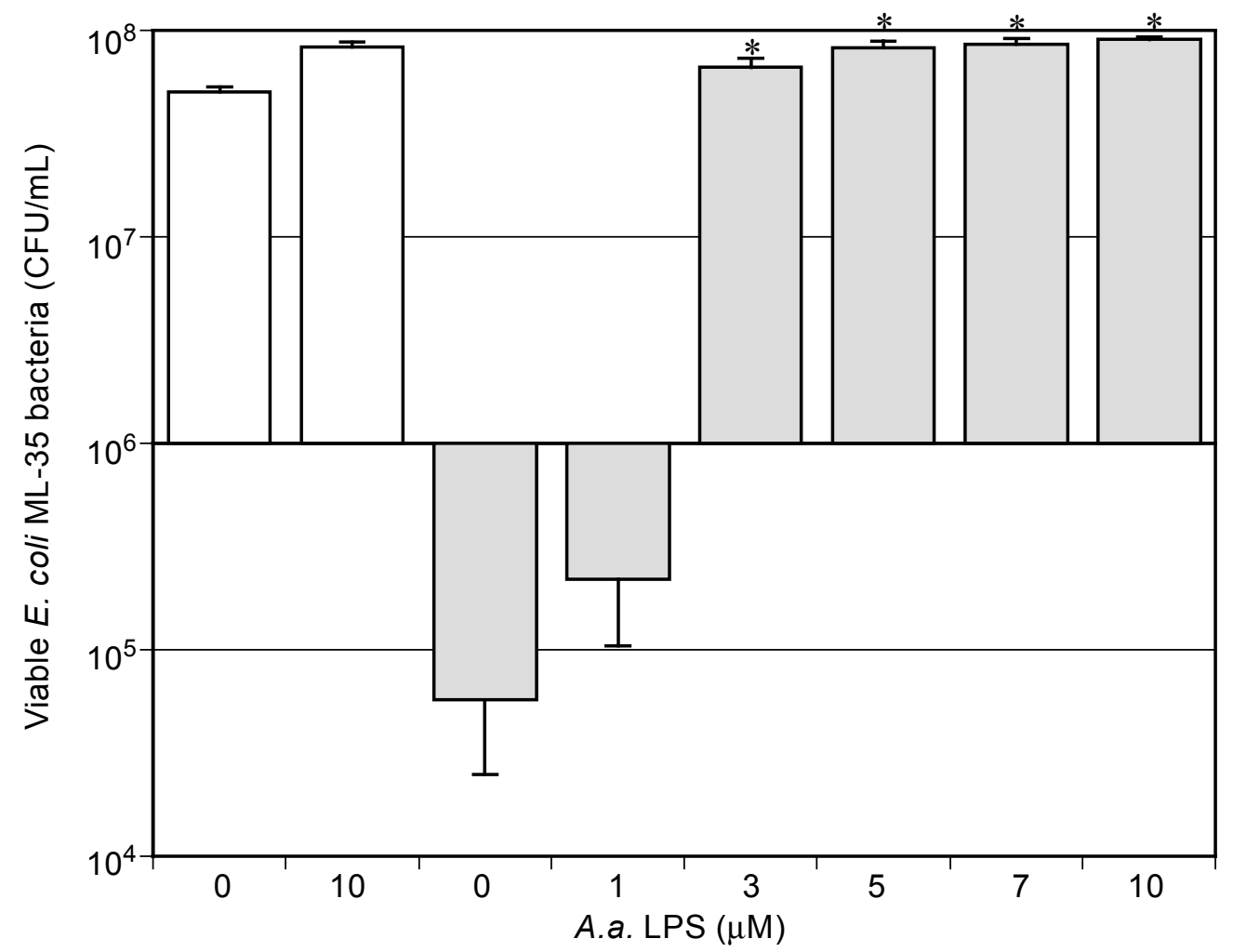

Conditions

Viable bacteria $\left(10^{6} \mathrm{CFU} / \mathrm{ml}\right)$

S.E.

n P Value

\begin{tabular}{lrrrr}
\hline Control $\left(4 \mathrm{~h}, 37^{\circ} \mathrm{C}\right)$ & 50.564 & 2.753 & 4 & - \\
$10 \mu \mathrm{M}$ LPS & 83.043 & 4.403 & 4 & - \\
$10 \mu \mathrm{M}$ HNP-4 & 0.057 & 0.032 & 4 & - \\
$10 \mu \mathrm{M} \mathrm{HNP}-4+1 \mu \mathrm{M}$ A.a. LPS & 0.219 & 0.114 & 3 & 1.0 \\
$10 \mu \mathrm{M} \mathrm{HNP}-4+3 \mu \mathrm{M}$ A.a. LPS & 66.522 & 6.492 & 4 & $<0.0001^{*}$ \\
$10 \mu \mathrm{M} \mathrm{HNP}-4+5 \mu \mathrm{M}$ A.a. LPS & 82.726 & 6.035 & 4 & $<0.0001^{*}$ \\
$10 \mu \mathrm{M}$ HNP-4 + $7 \mu \mathrm{M}$ A.a LPS & 85.385 & 5.385 & 2 & $<0.0001^{*}$ \\
$10 \mu \mathrm{M}$ HNP-4 $+10 \mu \mathrm{M}$ A.a LPS & 90.401 & 2.880 & 4 & $<0.0001^{*}$ \\
\hline
\end{tabular}

* Significantly different from the value with HNP-4 alone.

Figure 4.15. A.a. LPS blocks HNP-4 killing of $E$. coli ML-35.

E. coli ML-35 bacteria $\left(10^{6} / \mathrm{ml}\right)$ with 0 or $10 \mu \mathrm{M}$ A.a. Y4 LPS were incubated $4 \mathrm{~h}$ at $37^{\circ} \mathrm{C}$ and then diluted and plated (white bars). Alternatively, the bacteria were incubated with $10 \mu \mathrm{M} \mathrm{HNP}-4$ and various levels of purified A.a. LPS (gray bars). 


\section{CHAPTER 5. DISCUSSION}

\section{Physical Properties of Synthetic and Purified HNP-4}

Our laboratory was in a unique position to compare antibacterial activity of synthetic and purified HNP-4 because we had access to both. Our results show that both the synthetic and purified HNP-4 preparations had high purity. No other peptides or proteins were detected by mass spectrometry. Both preparations also appeared identical. They had the same molecular weight, which is the same as the molecular weight calculated from the published amino acid sequence of HNP-4. They also had the same low extinction coefficient expected for a peptide with one tyrosine residue.

Therefore, the activity of synthetic and purified HNP-4 should be the same. If there is any difference in activity, it must be due to something that could not be detected with the methods we used. For example, the molecular weight we measured is consistent with formation of three disulfide bonds by the 6 cysteines, but we would not be able to detect if the bonds were all paired correctly (1 to 6,2 to 4 , and 3 to 5 ).

Synthetic HNP-4 is easier to obtain than purified HNP-4. Further studies will probably use synthetic HNP-4. Synthetic HNP-4 would also be more convenient for clinical applications, and there would be no concern about possible contamination by viruses or prions from human blood.

\section{Activity of Synthetic and Purified HNP-4 against the Standard Test Organism}

Our experiments showed no difference in the activity of synthetic and purified HNP-4 when tested under the same conditions against the standard gram-negative test organism E. coli ML-35. Synthetic or purified HNP-4 had about the same activity as HNP-1. Our results do not support the conclusion that HNP-4 is more active than other alpha-defensins against gram-negative bacteria.

Although HNP-4 has a much different sequence than the other alpha-defensins, the difference does not have a large effect on activity against E. coli ML-35. Therefore, HNP-4 does not seem to have a special role in helping neutrophils kill gram-negative bacteria.

\section{Binding of HNP-4 to $E$. coli LPS}

The results of our experiments showed that purified E. coli LPS is able to absorb HNP-4 and block its activity. A ratio of about one LPS to two HNP-4 was enough to block activity. Therefore, HNP-4 binds to LPS from bacteria that are killed by HNP-4. 
The 1:2 ratio of LPS to HNP-4 could indicate that two molecules of HNP-4 form a dimer in solution, and that one HNP-4 dimer binds to one LPS molecule. A recent article reported that HNP-4 forms a dimer (21). The 1:2 ratio could also indicate that there are multiple binding sites for HNP-4 on LPS. Two HNP-4 monomers might bind at the same time to different sites on LPS. But it is not certain that the 1:2 ratio of blocking indicates a binding ratio. Our approach to detecting binding by measuring blocking of HNP-4 activity is very indirect. Other methods are needed to measure HNP-4 binding to LPS.

\section{LPS as the Receptor for HNP-4}

Our results show that purified lipid A did not absorb HNP-4 and block killing by HNP-4. Although lipid A has two negatively-charged phosphate groups, the cationic HNP-4 did not bind strongly to these anionic groups. We also found that LPS with the fatty acids removed from lipid A blocked as well as intact LPS. These results rule out lipid A as the binding site for HNP-4.

Table 5.1 summarizes results that indicates that the LPS inner core is the site where HNP-4 binds. Ra LPS with no oligosaccharide blocked as well as LPS. These results rule out oligosaccharide as the binding site for HNP-4. Rc LPS with a complete inner core but only part of the outer core blocked as well as Ra LPS, which has a complete inner and outer core. The outer core or the outer core plus oligosaccharide were not needed to absorb HNP-4 and block killing.

The inner core of LPS (which includes Kdo units, heptoses, phosphate, and phosphoryl- and pyrophosphoryl-ethanolamine groups) may be the HNP-4 binding site. Binding of HNP-4 to the inner core of LPS can account for all of the ability of LPS or LPS fragments to block HNP-4 activity. These results suggest that the LPS inner core is the binding site for HNP-4 on the surface of gram-negative bacteria.

Our experiments found that the Rc mutant E. coli J5 was more sensitive than E. coli ML-35 to killing by HNP-4. In other experiments (not shown), E. coli J5 was found to be less sensitive to killing by HNP-1 than $E$. coli ML-35. HNP-1 at $5 \mu \mathrm{M}$ killed $99 \%$ of E. coli ML-35 and $10 \mu \mathrm{M}$ was needed for $99 \%$ killing of E. coli J5.

Although the results need to be confirmed with side by side testing of HNP-1 and HNP-4 within the same experiment, these results suggest that HNP-1 is more effective against wild-type organisms, and HNP-4 is more effective against rough strains that have a complete inner core but lack the outer core and oligosaccharide. 
Table 5.1. Concentrations of LPS or LPS fragments that block $10 \mu \mathrm{M}$ HNP-4.

\begin{tabular}{lc}
\hline LPS or fragment & Blocking concentration $(\mu \mathrm{M})$ \\
\hline LPS (O111:B4) & 5 \\
Rough (Ra) LPS & 5 \\
Rough (Rc) LPS & 5 \\
Rough (Re) LPS & 10 \\
Kdo2-lipid A & 20 \\
Lipid A & $>>20$ \\
\hline
\end{tabular}

Recent studies show that HNP-1, -2 , and -3 have a lectin-like ability to bind to the carbohydrate part of glycoproteins $(7,60)$. Binding to glycoproteins on the surface of virus particles contributes to the ability of alpha-defensins to interfere with infection by herpes simplex virus (HSV) and human immunodeficiency virus-1 (HIV-1). HNP-4 was reported to not have lectin activity, but HNP-4 was more effective than HNP 1-3 in blocking HIV-1 infection (61). Binding of HNP-4 to heparan sulfate, which is a receptor for the HSV virus on human cells, was reported to contribute to antiviral activity. Heparin sulfate is a polysaccharide with many negative charges, which could attract the positively-charged HNP-4.

Our results suggest that HNP-4 may have lectin-like activity, because it binds to the Kdo units of Kdo2-lipid A. It binds stronger to Re LPS, which has three Kdo units, and binds even stronger to Rc LPS, which has heptose units in addition to Kdo units. On the other hand, negative charges on the inner core may account for binding of the cationic HNP-4. Each Kdo unit has a negative charge, and the phosphate, phosphoryl, and pyrophosphoryl units have negative charges. Therefore, binding of HNP-4 to the inner core could be explained by binding of positive to negative charges rather than binding of HNP-4 to specific sugars such as Kdo or heptose.

\section{Activity of HNP-4 against $A$.a.}

Our results showed that HNP-4 was similar to HNP-1 in having little or no activity against $A . a$. HNP-4 did not kill A.a. HNP-4 was able to partially inhibit growth, but inhibition did not increase as the HNP-4 concentration increased. This leads us to believe that A.a. is resistant in vitro to all the human leukocyte alphadefensins including HNP-4. 
If HNP-4 was especially active against all gram-negative bacteria including A.a. and other periodontal pathogens, then the results would raise a question of how the bacteria can survive in periodontal pockets in contact with neutrophils and defensins. The amount of HNP-4 in neutrophils may be too small to control the periodontal pathogens in vivo. However, the results seem to indicate that periodontal pathogens survive and cause disease because they are resistant to all of the alpha-defensins.

Synthetic HNP-4 does not seem to have the potential for clinical use to prevent or treat periodontal disease. Other agents such as protegrins or even polymyxin B might have greater potential. However, it is important to note that our experiments tested only one strain of one periodontal pathogen. We would need to test HNP-4 against a broader assortment of bacteria before concluding that HNP-4 is not effective against periodontal pathogens.

\section{Binding of HNP-4 to $A$.a. LPS}

LPS preparations purified from E. coli and A.a. were identical in their ability to block HNP-4. Both showed the same blocking ratio of one LPS to two HNP-4. Therefore, A.a. resistance to HNP-4 is not a result of failure of HNP-4 to bind to A.a. LPS. Something else must explain resistance of $A$. $a$. and probably other periodontal pathogens to HNP-4.

There are four general mechanisms of antibiotic resistance (62-64): (a) The micro-organism is able to destroy or inactivate the antibiotic; (b) The antibiotic does not get through the outer layers of the cell; (c) The antibiotic gets into the cell but is pumped back out; (d) The micro-organism is able to avoid effects of the antibiotic by using a different metabolic pathway that is not blocked by the antibiotic.

A.a. may produce a factor that destroys or inactivates HNP-4 and other alphadefensins. There could be an enzyme such as a protease that attacks defensins and is released from the bacteria or located in the cell envelope. It's also possible that HNP-4 binds to LPS on the surface but can't get through the outer membrane, peptidoglycan layer, and periplasm to get to the inner membrane.

HNP-4 and other CAPs probably do not have to get into the cytoplasm of bacteria in order to have antibacterial activity. Damage at the inner membrane accounts for killing of gram-negative bacteria by alpha-defensins $(65,66)$. Therefore, pumping HNP-4 out of the bacteria is probably not an important mechanism of resistance.

It's also unlikely that bacteria could survive an attack by HNP-4 on the inner membrane. There's no alternative pathway that the bacteria can use to make energy to grow and multiply if their inner membranes are leaky. Further studies are needed to determine the mechanism of resistance of periodontal pathogens to human leukocyte alpha-defensins. 


\section{LIST OF REFERENCES}

1. Schiött, C.R., Löe, H. (1969) The origin and variation in the number of leukocytes in the human saliva. $J$ Periodontal Res 4:24-26.

2. Schiött, C.R., Löe, H. (1970) The origin and variation in number of leukocytes in the human saliva. J Periodontal Res 5:36-41.

3. Woolweaver, D.A., Koch, G.G., Crawford, J.J., Lundblad, R.L. (1972) Relation of the orogranulocytic migratory rate to periodontal disease and blood leukocyte count: a clinical study. $J$ Dent Res 51:929-939.

4. Thomas, E.L., Lehrer, R.I., Rest R.F. (1988) Human neutrophil antimicrobial activity. Rev Infect Dis 10:S450-456.

5. Ganz, T. (2003) Defensins: antimicrobial peptides of innate immunity. Nat Rev Immun 3:710-720.

6. Selsted, M.E., Ouellette, A.J. (2005) Mammalian defensins in the antimicrobial immune response. Nat Immunol 6:551-557.

7. Lehrer, R.I. (2007) Multispecific myeloid defensins. Curr Opin Hematol 14:16-21.

8. Lehrer, R.I., Ganz, T., Selsted, M.E. (1991) Defensins: endogenous antibiotic peptides of animal cells. Cell 64:229-230.

9. Pisano, E., Cabras, T., Montaldo, C., Piras, V., Inzitari, R., Olmi, C., Castagnola, M., Messana, I. (2005) Peptides of human gingival crevicular fluid determined by HPLC-ESI-MS. Eur J Oral Sci 113:462-468.

10. Lundy, F.T., Orr, D.F., Shaw, C., Lamey, P.J., Linden, G.J. (2005) Detection of individual human neutrophil alpha-defensins (human neutrophil peptides 1, 2 and 3) in unfractionated gingival crevicular fluid-a MALDI-MS approach. Mol Immunol 42:575-579.

11. Martin, E., Ganz, T., Lehrer, R.I. (1995) Defensins and other endogenous peptide antibiotics of vertebrates. J Leukoc Biol 58:128-136.

12. Bals, R. (2000) Epithelial antimicrobial peptides in host defense against infection. Respir Res 1:141-50.

13. Tossi, A., Sandri, L. (2002) Molecular diversity in gene-encoded, cationic antimicrobial polypeptides. Curr Pharm Des 8:743-761. 
14. Lehrer, R.I., Ganz, T. (1996) Endogenous vertebrate antibiotics: defensins, protegrins, and other cysteine-rich antimicrobial peptides. Ann NYAcad Sci 797:228-239.

15. Bulet, P., Stöcklin, R., Menin, L. (2004) Anti-microbial peptides: from invertebrates to vertebrates. Immunol Rev 198:169-184.

16. Thomma, B.P., Cammue, B.P., Thevissen, K. (2002) Plant defensins. Planta 216:193-202.

17. Ganz, T., Selsted, M.E., Szklarek, D., Harwig, S.S., Daher, K., Bainton, D.F., Lehrer, R.I. (1985) Defensins: natural peptide antibiotics of human neutrophils. J Clin Invest 76:1427-1435.

18. Lehrer, R.I. (2004) Primate defensins. Nat Rev Microbiol 2:727-738.

19. Wilde, C.G., Griffith, J.E., Marra, M.N., Snable, J.L., Scott, R.W. (1989) Purification and characterization of human neutrophil peptide 4 , a novel member of the defensin family. J Biol Chem 264:11200-11203.

20. Wu, Z., Ericksen, B., Tucker, K., Lubkowski, J., Lu, W. (2004) Synthesis and characterization of human alpha-defensins 4-6. J Pept Res 64:118-125.

21. Szyk, A., Wu, Z., Tucker, K., Yang, D., Lu, W., Lubkowski, J. (2006) Crystal structures of human alpha-defensins HNP4, HD5, and HD6. Protein Sci 15:2749-2760.

22. Genco, R.J. (1996) Current view of risk factors for periodontal diseases. $J$ Periodontol 67(Suppl):1041-1049.

23. Fenesy, K.E. (1998) Periodontal disease: an overview for physicians. Mt Sinai $J$ Med 65:362-369.

24. Socransky, S.S., Haffajee, A.D. (2005) Periodontal microbial ecology. Periodontol 38:135-187.

25. Horz, H.P., Conrads, G. (2007) Diagnosis and anti-infective therapy of periodontitis. Expert Rev Anti Infect Ther 5:703-715.

26. Miyasaki, K.T., Bodeau, A.L., Ganz, T., Selsted, M.E., Lehrer, R.I. (1990) In vitro sensitivity of oral, gram-negative, facultative bacteria to the bactericidal activity of human neutrophil defensins. Infect Immun 58:3934-3940.

27. Miyasaki, K.T., Lehrer, R.I. (1998) Beta-sheet antibiotic peptides as potential dental therapeutics. Int J Antimicrob Agents 9:269-280. 
28. Miyasaki, K.T., Bodeau, A.L., Selsted, M.E., Ganz, T., Lehrer, R.I. (1990) Killing of oral, gram-negative, facultative bacteria by the rabbit defensin, NP-1. Oral Microbiol Immunol 5:315-319.

29. Miyasaki, K.T., Iofel, R., Oren, A., Huynh, T., Lehrer, R.I. (1988) Killing of Fusobacterium nucleatum, Porphyromonas gingivalis and Prevotella intermedia by protegrins. J Periodontal Res 33:91-98.

30. Miyasaki, K.T., Iofel, R., Lehrer, R.I. (1997) Sensitivity of periodontal pathogens to the bactericidal activity of synthetic protegrins, antibiotic peptides derived from porcine leukocytes. J Dent Res 6:1453-1459.

31. Chen, J., Falla, T.J., Liu, H., Hurst, M.A., Fujii, C.A., Mosca, D.A., Embree, J.R., Loury, D.J., Radel, P.A., Cheng Chang, C., Gu, L., Fiddes, J.C. (2000) Development of protegrins for the treatment and prevention of oral mucositis: structure-activity relationships of synthetic protegrin analogues. Biopolymers 55:88-98.

32. Bush, K., Macielag, M., Weidner-Wells, M., (2004) Taking inventory: antibacterial agents currently at or beyond phase 1. Curr Opin Microbiol 7:466-476.

33. Raetz, C.R. (1990) Biochemistry of endotoxins. Annu Rev Biochem 59:129170 .

34. Wheat, RW. (1992) Bacterial Morphology and Ultrastructure. In Zinsser Microbiology. (W.K. Joklik, H.P. Willett, D.B. Amos, C.M. Wilfert, eds) Appleton and Lang, Norwalk, Connecticut/San Mateo, California, 18-30.

35. Elsbach, P. (1998) The bactericidal/permeability-increasing protein (BPI) in antibacterial host defense. J Leukoc Biol 64:14-18.

36. Morrison, D.C., Jacobs, D.M. (1976) Binding of polymyxin B to the lipid A portion of bacterial lipopolysaccharides. Immunochemistry 13:813-818.

37. Evans, M.E., Feola, D.J., Rapp, R.P. (1999) Polymyxin B sulfate and colistin: old antibiotics for emerging multi-resistant gram-negative bacteria. Ann Pharmacother 33:960-967.

38. Raetz, C.R., Whitfield, C. (2002) Lipopolysaccharide endotoxins. Annu Rev Biochem 71:635-700.

39. Perry, M.B., MacLean, L.L., Gmur, R., Wilson, M.E. (1996) Characterization of the O-polysaccharide structure of lipopolysaccharide from Actinobacillus actinomycetemcomitans serotype b. Infect Immun 64:1215-1219. 
40. Perry, M.B., MacLean, L.L., Brisson, J.R., Wilson, M.E. (1996) Structures of the antigenic O-polysaccharides of lipopolysaccharides produced by Actinobacillus actinomycetemcomitans serotypes a,c,d and e. Eur J Biochem 242:682-688.

41. Kaplan, J.B., Perry, M.B., MacLean, L.L., Furgang, D., Wilson, M.E., Fine D.H. (2001) Structural and genetic analyses of O-polysaccharide from Actinobacillus actinomycetemcomitans serotype f. Infect Immun 69:53755384.

42. Allen, C.A., Adams, L.G., Ficht, T.A. (1998) Transposon-derived Brucella abortus rough mutants are attenuated and exhibit reduced intracellular survival. Infect Immun 66:1008-1016.

43. Masoud, H., Weintraub, S.T., Wang, R., Cotter, R., Holt, S.C. (1991) Investigation of the structure of lipid A from Actinobacillus actinomycetemcomitans strain Y4 and human clinical isolate PO 1021-7. Eur J Biochem 200:775-781.

44. Ogawa, T. (1993) Chemical structure of lipid A from Porphyromonas (Bacteroides) gingivalis lipopolysaccharide. FEBS Lett 332:197-201.

45. Hashimoto, M., Asai, Y., Tamai, R., Jinno, T., Umatani, K., Ogawa, T. (2003) Chemical structure and immunobiological activity of lipid A from Prevotella intermedia ATCC 25611 lipopolysaccharide. FEBS Lett 543:98-102.

46. Sawada, N., Ogawa, T., Asai, Y., Makimura, Y., Sugiyama, A. (2007) Toll-like receptor 4-dependent recognition of structurally different forms of chemically synthesized lipid As of Porphyromonas gingivalis. Clin Exp Immunol 148:529-536.

47. Ogawa, T., Asai, Y., Hashimoto, M., Takeuchi, O., Kurita, T., Yoshikai, Y., Miyake, K., Akira, S. (2002) Cell activation by Porphyromonas gingivalis lipid A molecule through Toll-like receptor 4- and myeloid differentiation factor 88-dependent signaling pathway. Int Immunol 14:1325-1332.

48. Lowry, O.H., Rosebrough, N.J., Farr, A.L., Randall, R.J. (1951) Protein measurement with the Folin phenol reagent. J Biol Chem 193:265-275.

49. Millar, S.J., Goldstein, E.G., Levine, M.J., Hausmann, E. (1986) Modulation of bone metabolism by two chemically distinct lipopolysaccharide fractions from Bacteroides gingivalis. Infect Immun 51:302-306. 
50. Mansheim, B.J., Onderdonk, A.B., Kasper, D.L. (1978) Immunochemical and biologic studies of the lipopolysaccharide of Bacteroides melaninogenicus subspecies asaccharolyticus. J Immunol 120:72-78.

51. Westphal, O., Jann, K. (1965) Bacterial lipopolysaccharides. Methods in Carbohydrate Chemistry 5:83-91.

52. Ding, H.F., Nakoneczna, I., Hsu, H.S. (1990) Protective immunity induced in mice by detoxified salmonella lipopolysaccharide. J Med Microbiol 31:95102.

53. Qureshi, N., Takayama, K., Heller, D., Fenselau, C. (1983) Position of ester groups in the lipid A backbone of lipopolysaccharides obtained from Salmonella typhimurium. J Biol Chem 258:12947-12951.

54. Tanamoto, K., Azumi, S., Haishima, Y., Kumada, H., Umemoto, T. (1997) Endotoxic properties of free lipid A from Porphyromonas gingivalis. Microbiology 143:63-71.

55. Davis, B.D., Mingioli, E.S. (1950) Mutants of Escherichia coli requiring methionine or vitamin B12. J Bacteriol 60:17-28.

56. Aurell, C.A., Wistrom, A.O. (1998) Critical aggregation concentrations of gram-negative bacterial lipopolysaccharides. Biochem Biophys Res Commun 253:119-123.

57. Heinrichs, D.E., Yethon, J.A., Whitfield, C. (1998) Molecular basis for structural diversity in the core regions of the lipopolysaccharides of Escherichia coli and Salmonella enterica. Mol Microbiol 30:221-232.

58. Gill, S.C., von Hippel, P.H. (1989) Calculation of protein extinction coefficients from amino acid sequence data. Anal Biochem 182:319-326. Erratum in: Anal Biochem (1990) 189:283.

59. Raetz, C.R., Garrett, T.A., Reynolds, C.M., Shaw, W.A., Moore, J.D., Smith, D.C., Jr., Ribeiro, A.A., Murphy, R.C., Ulevitch, R.J., Fearns, C., Reichart, D., Glass, C.K., Benner, C., Subramaniam, S., Harkewicz, R., Bowers-Gentry, R.C., Buczynski, M.W., Cooper, J.A., Deems, R.A., Dennis, E.A. (2002) Kdo2-lipid A of Escherichia coli, a defined endotoxin that activates macrophages via TLR-4. J Lipid Res 47:1097-1111.

60. Hazrati, E., Galen, B., Lu, W., Wang, W., Ouyang, Y., Keller, M.J., Lehrer, R.I., Herold, B.C. (2006) Human alpha- and beta-defensins block multiple steps in herpes simplex virus infection. J Immunol 177:8658-8666. 
61. Wu, Z., Cocchi, F., Gentles, D., Ericksen, B., Lubkowski, J., DeVico, A., Lehrer, R.I., Lu, W. (2005) Human neutrophil $\alpha$-defensin 4 inhibits HIV-1 infection in vitro. FEBS Lett 579:162-166.

62. Willet, H.P. (1992) Bacterial Morphology and Ultrastructure. In Zinsser Microbiology. (W.K. Joklik, H.P. Willett, D.B. Amos, C.M. Wilfert, eds) Appleton and Lang, Norwalk, Connecticut/San Mateo, California, 182-185.

63. Tenover, F.C. (2006) Mechanisms of antimicrobial resistance in bacteria. Am J Infect Control 34:S3-10.

64. Lim, S.M., Webb, S.A. (2005) Nosocomial bacterial infections in Intensive Care Units. I: Organisms and mechanisms of antibiotic resistance. Anaesthesia 60:887-902.

65. Lehrer, R.I., Barton, A., Daher, K.A., Harwig, S.S., Ganz, T., Selsted, M.E. (1989) Interaction of human defensins with Escherichia coli. Mechanism of bactericidal activity. $J$ Clin Invest 84:553-561.

66. Kagan, B.L., Selsted, M.E., Ganz, T., Lehrer, R.I. (1990) Antimicrobial defensin peptides form voltage-dependent ion-permeable channels in planar lipid bilayer membranes. Proc Natl Acad Sci U S A 87:210-214. 


\section{VITA}

George Emil Hilal was born in Palestine on August 26, 1978. He received his Bachelor of Science degree in Microbiology from the University of Florida in 2001. He then received his D.M.D. degree from the University of Louisville in 2005.

He is currently enrolled as a graduate student in the Department of Periodontology at the University of Tennessee Health Science Center College of Dentistry. He will receive his degree of Master of Dental Science in May of 2008. 